\title{
The implementation of learning strategies in the design of an on- line medical course supplement
}

\author{
Lee Ann Hill \\ West Virginia University
}

Follow this and additional works at: https://researchrepository.wvu.edu/etd

\section{Recommended Citation}

Hill, Lee Ann, "The implementation of learning strategies in the design of an on-line medical course supplement" (1999). Graduate Theses, Dissertations, and Problem Reports. 3671.

https://researchrepository.wvu.edu/etd/3671

This Dissertation is protected by copyright and/or related rights. It has been brought to you by the The Research Repository @ WVU with permission from the rights-holder(s). You are free to use this Dissertation in any way that is permitted by the copyright and related rights legislation that applies to your use. For other uses you must obtain permission from the rights-holder(s) directly, unless additional rights are indicated by a Creative Commons license in the record and/ or on the work itself. This Dissertation has been accepted for inclusion in WVU Graduate Theses, Dissertations, and Problem Reports collection by an authorized administrator of The Research Repository @ WVU.

For more information, please contact researchrepository@mail.wvu.edu. 


\title{
THE IMPLEMENTATION OF LEARNING STRATEGIES
}

\section{IN THE DESIGN OF AN ON-LINE MEDICAL COURSE SUPPLEMENT}

By

Lee Ann Hill

\author{
A DISSERTATION \\ Submitted to \\ The College of Human Resources and Education \\ At West Virginia University \\ in partial fulfillment of the requirements \\ for the degree of \\ Doctor of Education \\ In \\ Educational Psychology \\ Department of Advanced Educational Studies \\ Morgantown, West Virginia \\ 1999
}

Rayne S. Dennison PhD, chair

Marie A. Abate, PharmD

Patricia A. Haught, EdD

Anne H. Nardi, PhD

Richard T. Walls, PhD

Keywords: On-line Instruction, Learning Strategies, Instructional Design

Copyright 1999, Lee Ann Hill 


\title{
THE IMPLEMENTATION OF LEARNING STRATEGIES
}

\section{IN THE DESIGN OF AN ON-LINE MEDICAL COURSE SUPPLEMENT}

\author{
By \\ Lee Ann Hill
}

\begin{abstract}
Given the charge of integrating technology in the medical school curriculum, faculty members are faced with the challenge of designing new materials for their courses. Often, these materials become on-line resources such as hypermedia and electronic communication. Strategies may assist students who are unfamiliar with on-line materials to use such materials more effectively. This study investigated the elaborative interrogation strategy used in conjunction with on-line materials to promote more efficient processing of difficult material. Twenty second-year medical students volunteered to participate in the study. The course in which they were enrolled required the use of an on-line lecture supplement. The elaborative interrogation intervention consisted of a written page of instruction for including "why" questions in their independent study process. The control students were instructed to simply record their study behaviors during the intervention period. Results indicated no significant differences between groups with or without strategy instruction. It is likely that as advanced students, medical students have existing strategies that were as effective as the strategy used during the intervention. As an auxiliary study of the overall effects of using on-line materials, exam scores of the current students were compared to the exam scores of a cohort group from the previous year who did not use on-line materials. The students from the previous year performed significantly better than the students from
\end{abstract}


the current year on a similar examination of content knowledge. It is possible that volunteers in the current study were particularly anxious about using on-line materials due to the timing of the introduction of the strategy and lack of computer experience. Qualitative analysis of student feedback supports these assumptions. Future research should address the issues of timing of the presentation, more effective strategy training, and embedding the strategy instruction to increase student participation. 


\section{Acknowledgments}

I would like to thank all those who so diligently supported me during this research and during my time as a doctoral student. First, thanks to the students who volunteered their participation and followed through during a challenging time in their education. Great appreciation goes to Dr. James Sheil for kindly assisting me prior to, during, and after the study period to make sure my study was accurate and complete.

I extend my gratitude to the committee members who I was so fortunate to work with: to Marie Abate for initiating my interest in instructional technology with her projects; to Dick Walls for his excellent methodological advice and excellent musical entertainment; to Patty Haught for so many good research, publication, and conferencing opportunities; to Anne Nardi for providing a sense of stability from the very beginning of my graduate experience; and especially to Rayne Dennison, my friend and my chair, without whom this dissertation would never have been accomplished.

Special thanks to my good friend Mehdi Seyedmonir who assisted with my analyses. Thanks to the Friends and More of St. John's Parish for providing excellent and necessary diversions. Thanks to Glen "Iggi" Trail, for his reliable technical support and thank you to Rusty Russell for his valuable mentorship. Finally, I extend sincere appreciation to my parents and my fiancé Daniel, who with patience and tolerance endured the dissertation process with me. 


\section{Table of Contents}

List of Tables/Figures _ vii

Chapter 1: Introduction $\quad 1$

Context of the Study 3

Research Questions $\quad 4$

Chapter Two: Literature Review 6

$\begin{array}{ll}\text { The History of Hypermedia for Instruction } & 6\end{array}$

Behaviorism $\quad 6$

Programmed Instruction $\quad 6$

\begin{tabular}{ll} 
Cognition & 8 \\
\hline
\end{tabular}

Information Processing 8

$\begin{array}{ll}\text { Dual Coding } & 10\end{array}$

$\begin{array}{ll}\text { Constructivism } & 13\end{array}$

Instructional Design for CAI 14

Learning Strategies $\quad 17$

Self-Questioning Strategies $\quad 18$

Elaborative Interrogation 19

$\begin{array}{ll}\text { Strategies within Constructivism } & 23\end{array}$

Conclusion 24

Statement of the Problem 26

Chapter Three: Method 28

Participants 28

Design $\quad 29$

Materials 31

$\begin{array}{ll}\text { Pre- and Post- Surveys } & 31\end{array}$

Block I Exam (delayed post-test) $\quad 32$

Pre- and Post- Tests 32

On-line Lecture Supplement $\quad 32$

Strategy Instruction $\quad 33$

Study Activity Matrix $\quad 35$

Additional Course Materials $\quad 35$

$\begin{array}{ll}\text { Procedure } & 39\end{array}$

$\begin{array}{ll}\text { Chapter Four: Results } & 42\end{array}$

Preliminary Analyses $\quad 42$

Research Question One $\quad 43$

Research Question Two $\quad 45$

Research Question Three $\quad 47$ 
Qualitative Analysis $\quad 48$

Student Generated Questions $\quad 48$

Post-Survey Responses $\quad 50$

Lecture Supplement 51

Electronic Communication $\quad 52$

On-Line Testing $\quad 53$

Animations $\quad 53$

Chapter Five: Discussion and Conclusions 56

Research Question One $\quad 56$

Research Question Two 59

Research Question Three $\quad 60$

General Study Limitations $\quad 61$

Future Research 63

Conclusions for Future Practice 64

$\begin{array}{lc}\text { References } & 66\end{array}$

Appendixes

A. Suggestions for Creating Constructivist Materials 74

B. Introductory Frames on Morphemes $\quad 76$

C. Timeline of Study Procedure 78

D. Consent and Information Form 80

$\begin{array}{ll}\text { E. Pre-Survey } & 82\end{array}$

F. Post-Survey 84

G. Pre- and Post-test 86

H. Design of On-Line Course Supplement 89

I. Student Debriefing 91

J. "Why" Questions Submitted by Students 93

K. Subject Matter Expert Assessment of Questions and Answers Generated by the Students 97

L. Post-Interview Data 99

M. Study Matrix Data 105

$\begin{array}{ll}\text { Curriculum Vita } & 109\end{array}$ 


\section{List of Tables and Figures}

Tables

1. Means and Standard Deviations for MCAT Scores by Group 43

2. Means and Standard Deviations for Pre-Test Scores by Group 43

3. Means and Standard Deviations for Post-Test Scores by Group 44

4. Means and Standard Deviations for Pre-Post Scores by Group 45

5. Means and Standard Deviations for Group x Testing Occasion Analysis of Variance 46

6. Means and Standard Deviations for Exam Scores by Year 47

7. Means and Standard Deviations for Exam Scores by Volunteer 48

8. Analysis of "Why" Questions and Exam Questions 50

Figures

1. Learners Cognitive System 9

2. Research Design 30

3. Example On-Line Content Screen 34

4. Experimental Group Strategy Instructions 36

5. Control Group Strategy Instructions 37

6. Study Activity Matrix 38 


\section{The Implementation of Learning Strategies in the Design of an On-Line Medical Course Supplement \\ Chapter One}

\section{Introduction}

Key issues in designing effective instruction are instructional materials and media choice. Computer-aided instruction (CAI) has been part of curricula for many years in the form of programmed instruction, drill and practice courseware, and tutorials. More recent advances in technology provide educators with the capacity to develop interactive, graphic-intensive simulations, often known as Hypermedia. The term Hypermedia comes from the ideas of Hypertext and Multimedia. Hypertext, as defined by Myers and Burton (1994), is non-sequential writing, "free from the constraints of sequence imposed by books." (p. 9). Students can experience text information by linking separate pieces or "nodes" of information in a non-linear fashion according to their interests or learning styles. In addition to non-sequential text, Hypermedia includes sound, animation, and video (otherwise known as Multimedia) in the learning experience. Hypermedia can also add simulations to supplement or replace text material. Hypermedia can provide applications that are more similar to real-world problems and promote better transfer of knowledge. Considerable research has investigated the learning benefits and drawbacks of instruction presented via hypertext and Hypermedia (Nelson, 1993; Reed, Ayersman, \& Liu, 1995; Smeaton, 1991)

In a student-centered learning environment, as illustrated in a constructivist setting, the computer can play a role of either tutor, tutee, or both. As a tutor, according 
to Jonassen (1988), the computer delivers electronically programmed information. As a tutee, the computer becomes a world in which learners are free to explore. Allowing students to explore gives them the ability to control the environment and construct novel ideas in a manner conducive to a variety of learning styles and learning outcomes.

Current trends in courseware development, or the development of computer software for an educational purpose, rely on the tutee mode of computer applications. In the tutee mode, the computer serves as a "cognitive tool" for engaging learners in knowledge creation rather than knowledge reproduction. For example, a computer simulation allows learners to explore a virtual situation in which they create their own learning experience. The foundation for effective use of the computer as tutor and the computer as tutee is found in effective instructional design. The decision of how to utilize the computer in a learning environment is one of the components of a good instructional design plan.

Instructional designers address understanding and improving the process of knowledge acquisition. A Hypermedia-based environment can be used as an excellent means for the construction and reconstruction of knowledge (Jonassen, 1988). Programs with branching capabilities and variety in modality can adapt to the needs of each individual learner and facilitate the learning process. The instructional designer is responsible for prescribing methods of instruction that effectively and efficiently bring about such changes in students' knowledge and skills repertoire.

With the growing number of computers currently found in classrooms today, 
there is great need for attention in the design and development of appropriate CAI. An overriding theme in courseware design involves the recognition of individual differences and the importance of adapting courseware to fit the needs of the learner. Overall, effective CAI provides information in a meaningful context that allows the learner to activate prior knowledge and integrate new knowledge. Learners should have opportunity to acquire motivating strategies that also help them to learn, think, and remember. Ideally, the computer interface should emulate human intelligence and adapt the style, sequence, or content of the presentation or feedback to suit the learner (Duffy \& Jonassen, 1992).

\section{Context of the Study}

Salomon, Perkins, and Globerson (1991) examined technology as an intelligent tool for helping people learn and concluded that technology can redefine and enhance performance when students work in conjunction with machines that take part in cognitive processing. In addition, these technologies can equip people with transferable thinking skills and learning strategies. The problem is, such benefits cannot occur automatically as technologies advance, they rely on appropriate design (Jonassen, 1988) and appropriate learning strategies.

Authors have predicted the transition from teaching by spoken word, to teaching with printed text, to the current trend of using the computer in Health Sciences education e.g., on-line courses and computer-based animations (Billings, 1986). With the convenience of using the computer, more learning can take place outside the classroom, in the home or in the workplace. Educators, therefore, are often forced to re- 
create materials for independent use. It is necessary in this situation for educators to take on the role of instructional designers. This is very common in the medical professions with the increased need to share data and knowledge bases with colleagues at a distance.

The school of medicine in the current study has initiated the integration of technology into every classroom. The incoming class of medical students, the cohort of students following those in the current study, was required to lease lap top computers. In an effort to provide instructionally effective computer-based instruction, an instructional support team was asked to assist in the development of an interactive web-based supplement to the lectures of the Microbiology course. According to the course coordinator, the Immunology portion of the course for second-year medical students is typically the most difficult content for them to understand.

As part of this initiative, a web-based lecture supplement was developed to assist the learners with the Immunology material. This study investigates learning strategies, effective in text-based environments, used in conjunction with the on-line materials to promote more efficient processing of difficult material in a medical learning environment.

\section{$\underline{\text { Research Questions }}$}

Three research questions are addressed in the current investigation. First, are there differences between groups receiving learning strategy instruction versus receiving no strategy instruction in web-based learning? It was hypothesized that learners receiving strategy instruction would more effectively master content in 
immunology than those receiving no strategy instruction. Second, are on-line materials better than printed materials for learning lecture content? It was hypothesized that although the benefits of CAI could facilitate learning, learners who are not familiar with learning with computers will not perform as well as more experienced learners in future classes might. Therefore, learners in the current investigation would not perform as well as the previous groups who used traditional learning materials. Finally, Are volunteers different than students who declined participation? This third question was added after finding that students who declined to participate greatly outnumbered those who agreed to participate. It was hypothesized that given the small proportion of volunteers, those who did volunteer may somehow be different from those who did not volunteer. 


\section{Chapter Two}

\section{Literature Review}

The History of Hypermedia for Instruction

Although Hypermedia instruction is a current instructional tool, historically there have been several other types of computer-based instruction. Behaviorist theories initially incorporated programmed instruction; cognitive based approaches included drill and practice programs and tutorials; and constructivism applied simulations in computer-based learning.

\section{$\underline{\text { Behaviorism }}$}

Skinner's operant conditioning theory directed research on computer-based instruction from a behavioral standpoint (Simonson \& Thompson, 1997). Skinner incorporated both sequenced instruction and immediate reinforcement in the innovation of teaching machines. A teaching machine is a mechanical device that gives reinforcement only for correct responses in the form of confirmation for correct answers, opportunity to move on to new material, or the opportunity to operate the equipment (Gredler, 1997). Teaching machines are most commonly used in conjunction with the method of Programmed Instruction.

Programmed Instruction. B.F. Skinner described programmed instruction as the mechanical anticipation of the computer (Simonson \& Thompson, 1997). Programmed instruction takes advantage of early discoveries in experimental analysis of behavior as it relates to teaching and learning and corrects the basic fault of lack of immediate reinforcement and incorporates principles of high and relevant activity rate, successive 
approximation, and mastery progression (Skinner, 1989; West \& Hamerlynck, 1992).

The materials of programmed instruction, in conjunction with the teaching machine, are entirely self-paced and stand-alone. That is, the entire process requires no teacher intervention. Subject matter is broken down into small units called frames. Frames are sequenced from simple to complex. As students work through the frames, they are shaped to compose an answer, not simply to select one (Vargas \& Vargas, 1991). Appendix B provides an example set of frames that teaches "morphemes" (Gredler, 1997).

Researchers found that programmed instruction worked and programmed texts were as effective as teaching machines but that neither mechanical machines nor printed texts produced better results than more traditional methods of teaching (e.g., textbook and lecture). In fact, most research showed little support for the use of programmed instruction other than as an alternative to conventional instruction, such as in correspondence education or remedial instruction (Simonson \& Thompson, 1997). Vargas and Vargas (1991) suggested that the failure of programmed instruction may have been due to inadequacy to perform better than less expensive alternative techniques.

Although not entirely successful as an instructional approach, programmed instruction eventually brought about many considerations for computer-based instruction. These considerations include: (a) stating objectives in terms of desired outcome behaviors, (b) assessing a student's previously acquired behaviors before any instruction, (c) placing learners in a sequence of instruction where they can achieve at 
the $90 \%$ level, but before new instructional activities where they would not be this successful, (d) using teaching machines to reinforce and strengthen desired behaviors and, (e) recording a learner's progress through a lesson to gain feedback for revising the lesson. While the principles of programmed instruction are educationally sound and the idea of individualized instruction is still acclaimed, the innovation did not last more than 10 years (Simonson \& Thompson, 1997). Current CAI, such as Hypermedia, on the other hand, has many motivating qualities, including greater learner control during individualized instruction.

\section{$\underline{\text { Cognition }}$}

Cognitive theory of learning infers the individual nature of knowledge acquisition. According to this theory, the mind is an active organizer of information. The mental operations required for the acquisition and organization of knowledge are reflected in the model of information processing (Gredler, 1997). The core of cognition, from an information processing perspective, centers on the processes by which individuals perceive, encode, and store information in memory. Schema, or knowledge storage networks, are developed on the basis of one's own experience and the processing of information is dependent upon personal interpretation and organization (Bransford \& Johnson, 1972).

Information Processing. The Information Processing Model equates the concept of linking nodes of information with the structure of human memory (Anderson, 1990). Information from the external world originates at the sensory registers that hold large quantities of information for only a short amount of time. If some pattern recognition is 
formed with this information, it can be entered into short-term memory or working memory. Short-term memory is more durable but still only lasts for a few seconds. If the information is then treated with some cognitive operation (like elaboration or organization) the information can be stored indefinitely in long term memory.

Learners, as active interpreters or processors of information, store and retrieve information, or knowledge, in memory much like a Hypermedia system represents information in a computer program (see Figure 1). As the learner interacts with the content material, new knowledge becomes reorganized to fit existing knowledge structures. Cobb (1988) presumes that instruction should facilitate "profound cognitive restructuring and conceptual reorganizations." These restructurings and reorganizations are what take place when information is transferred from short-term to long-term memory, or in other words, is encoded.

Figure 1. Visual Representation of the Learners' Cognitive System.

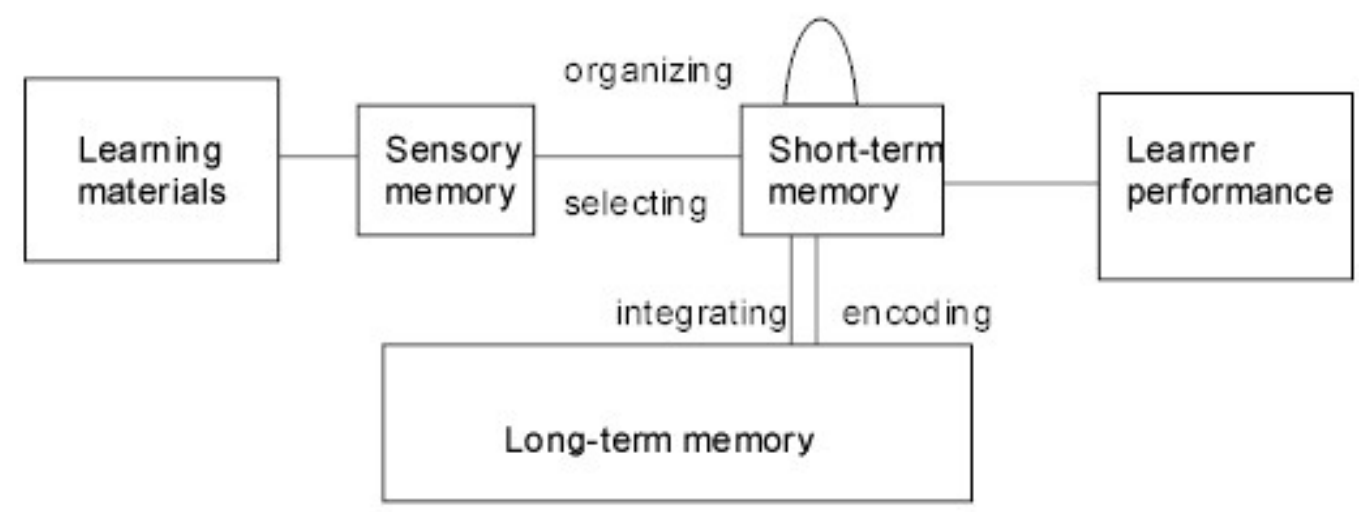

The evolution of Hypermedia has brought forth questions about the role of cognitive theory in learning with computers (Nelson, 1993). Proponents of computer- 
aided instruction emphasize the role of Hypermedia as a facilitator of cognitive processing (Jonassen, 1994; Nelson, 1993; Scheidler, 1993). Hypermedia systems may organize information in ways very similar to human memory organization. The assumption is that knowledge presented in Hypermedia format can be readily transferred to the mind of the user (Nelson, 1993). Nonlinear and nonsequential in nature, Hypermedia is a powerful tool for researchers who study how students interact with instruction as they learn. Therefore, an information processing model of learning is comparable to the Hypermedia format.

Another important aspect of the cognitive perspective is the study of dual coding. The research reviewed for the current study addresses the format of material presented to learners. Dual coding has implications for instructional design and for learner strategy use since it involves both selections of learning materials and encoding.

Dual Coding. Dual coding theory addresses encoding, or transforming information into a form suitable for storage in long-term memory (Anderson, 1990). The formation of an integrated piece of multimedia can best be understood by examining the individual components that form the whole (Poohkay \& Szabo, 1995). According to dual coding theory, information is said to occur in two forms: verbal (linear) or visual (spatial). Information can be transformed into a set of symbols (or code) that can be stored in long-term memory and later retrieved and utilized. Dual coding theory suggests that when information is represented in both codes rather than one it is remembered better. If two different sorts of information about an experience are stored, the chances improve that one code or the other will support memory later. 
The combination of text, audio, video, graphics, and animation can provide learners with a rich environment in which to acquire knowledge and skills. Furthermore, pictures of objects are better remembered than words naming the objects (Levin, 1983; Mayer \& Anderson, 1992; Paivio, 1971). For example, if a learner needs to learn about embryologic development in a histology class and is presented with both text and graphics (or dual modes), the learner is more likely to encode, or remember the information.

Mayer and Anderson (1992) utilized animations and narrations to demonstrate the effects of dual coding at the referential level. Two experiments were designed to compare the problem-solving and verbal retention performance of college students who received concurrent versus successive presentation of animations and narrations of how a system (pump or car brakes) works. The results demonstrate that animation per se does not necessarily improve students' understanding of how a pump or a brake works. When animation was presented concurrently with narration, students demonstrated large improvements in problem-solving transfer over the no-instruction group. Contiguity of words and pictures during instruction encourages learners to build connections between their verbal and visual representations of incoming information, which in turn supports problem-solving transfer.

Advanced computer software and talented graphic engineers may work together to turn simple illustrations into complex animations. Pictures have proven to be excellent learning tools but to make that picture move or change according to the concept to be learned can be even more effective. Rieber (1990) integrated a 13-year 
span of empirical research on animation in computer aided instruction. He first emphasized the obvious, practical, and rational use of animation to satisfy Gagné's attention-getting event of instruction (Gredler, 1997). The review of literature isolated three major recommendations: (a) animation should be incorporated only when its attributes are congruent to the learning task, (b) when learners are novices in the content area, they may not know how to attend to relevant cues or details provided by animation, and (c) animation's greatest contributions to CAI may lie in interactive graphic applications.

Poohkay and Szabo (1995) concur with the latter assumption in stating that the real contribution of animation may be in the realm of interactive graphics. They further support Rieber's claims by also recommending simpler animations to optimize learning for beginners. In addition, they recommend enhancing the encoding power of graphics or animations by engaging the learners in the creation and use of mental imagery during instruction.

Mayer and Sims (1994) refuted Rieber's second assumption about novice learners when they investigated students with low prior knowledge in a computer-generated animation/narration situation. The inexperienced students found benefit in pictures presented with words. Additional results were consistent with dual coding theory. Students with high spatial ability built mental connections between visually-based and verbally-based representations as evidenced by their performance on outcome measures of content knowledge. For example, students who were determined to have high spatial ability, when presented with concurrent presentation of animation and 
narration, were able to generate $50 \%$ more creative solutions to transfer problems about scientific systems than those with low spatial ability.

Constructivism

Behaviorists study only observable learner performance. Conversely, cognitive psychologists study what learners know and how they come to acquire knowledge.

One question concerning cognitive theory of learning in instructional systems technology asks if the mind is merely a tool for reproducing the real world, or does the mind produce its own, unique conception of events or objects which is based on individual conceptions of reality? Constructivists, such as Jonassen (1991) and Wilson (1993), suggest that if we construct meaning for objects and events through the interpretation of our own perceptions of them, based on past experiences and beliefs, then each individual possesses a unique mental reality.

From a theoretical perspective, the constructivist notion of learner-centered presentations contends that rather than simply providing data, the presenter must help learners construct meaning from frameworks and activities so they may interpret the information through a different scheme or structure. According to this perspective, participant interaction with the presenter, the content, and other participants are equally important. In sum, a learner-centered presentation must provide experiences that allow learners to link prior knowledge to the content, dispel misconceptions, and improve their knowledge base (Cognition and Technology Group at Vanderbilt, 1991; Garmston \& Wellman, 1994). Therefore, CAI designed with constructivist characteristics allows learners to be active, to build upon prior knowledge, to challenge 
the teacher's view, and reflect on knowledge and learning (Duffy \& Jonassen, 1992). The overall emphasis is on learning rather than on performance and instruction. Although instructional design applies to all types of instruction, there are many important factors to consider when designing for computers, especially from a constructivist framework.

\section{Instructional Design for CAI}

In current CAI applications we generally rely on cognitive and constructivist theories of learning to support instructional design practices. Making the distinction between the two theories is sometimes difficult in that each focuses on CAI construction of knowledge representation by the learner. This process is fairly consistent across the two theories.

One very important issue in designing CAI is the use of illustrations and animations. Computers can produce aesthetically pleasing and educationally valuable graphics. With the known positive effects of dual coding, instructional designers should use a mix of both text and animation when possible. From a cognitive perspective, materials that evoke both verbal and imaginal cues are more readily encoded or stored in memory.

Illustrations and animations in computer-based learning have been found to increase student interest, motivation, and curiosity (Rieber, 1991). They provide opportunities for learners to perceive intended context and span linguistic barriers. They also clarify and reinforce text and lecture material and sharpen powers of observation (ChanLin, 1994). Designers of visually-enhanced learning material need to 
consider individual differences (i.e., IQ and reading ability) in constructing task difficulty and the complexity of graphics, use of colors and cues, and sequence of presentation appropriate for the content and the learner. The use of color to produce aesthetically pleasing screens (or graphics) can employ scientifically derived principles of instructional design (Jonassen, 1988; Perkins, 1991; Schwier \& Misanchuk, 1995). Pedagogical and technological concerns have grown since the emergence of visuallyenhanced learning environments (Buck, 1995). The advantages of using new technology for creation and display of visual images include easy manipulation to fit the customized needs of the user and save production time and energy.

Perkins (1991) discussed three facets of instructional design related to constructivism and the production of computer aided instruction. The first facet is task analysis where tasks should display understanding, not just knowledge, and should include explanation, extrapolation, and evidence giving. For example, the designer should develop tasks that prompt the student to solve problems or use prior knowledge when introducing a new concept rather than prompting the student to repeat facts. The learner is involved in making sense not just learning information and routines. Task analysis is followed by the development of instructional strategies where information banks become places for working through ideas rather than just for recording information. Finally, assessment of the active use of knowledge requires measures of learning transfer. Technology can offer some types of on-line assessment. It is difficult, however, to address the subjective nature of evaluating open-ended student expressions of learning. 
Some designers have attempted to utilize constructivist principles as well as these facets of instructional design in the development of learning materials. A team of instructional designers, for example, found great success in utilizing constructivist principles in a teacher education course (Wager \& Lebow, 1995). Although their measures of success are not quantitative, the authors did cite the following student feedback: "The first real graduate course I've had," "A watershed in my thinking," and a standing ovation on the last day of class (p. 5). These authors make several suggestions for considering this type of theoretical basis in creating constructivist materials (See Appendix A). In addition, Jonassen (1991) states:

Designers use their objective tools (e.g., task analysis) to determine an objective reality, which they then try to map onto learners through embedding instructional strategies that control learning behavior with the following assumptions: We all agree on what reality is, and we all use essentially the same process for understanding it. (p. 9)

Despite the polarity between the rather strict behavioral approach and the openended nature of constructivism, the focus of designing CAI remains on the materials and the instruction. Especially from a cognitive/constructivist standpoint, however, a large part of the focus still must rest with the learner. Learners generally have ineffective strategies, such as the inability to monitor their own learning (Glenberg, 1986). Therefore, it seems important for learners to have good learning strategies, especially when learners are faced with stand-alone computer-based materials (no 
matter how effective). The current study further addresses instructional design in medical students and adds to the growing literature investigating learning from CAI.

\section{Learning Strategies}

Strategy instruction helps students become more effective and efficient learners. Learning strategies can be defined as a set of cognitive activities which help to facilitate or support learning (Jonassen, 1989). In order to combat the limitations of CAI, such as, shallow processing by the learner with the computer as tutor, Jonassen discussed implementing learning strategies as generative activities that foster learning and learning-to-learn. Imagery, for example, was recommended as a powerful retention technique that encodes elaborative information in a separate memory area thus providing another point of access for retrieval (Paivio, 1971). With the imagery strategy, learners can be trained to generate mental images or create physical images when working with courseware.

Students were also encouraged to employ information processing strategies to create a unique interpretation and encoding of information into memory. Jonassen (1989) describes a model of interrupting information presentation in computer courseware to insert a relevant strategy activity. There are many types of strategies in educational research. For example, information processing strategies (Mayer \& Sims, 1994; Paivio, 1971), study strategies (Kiewra, 1991; Weinstein, Ridley, Dahl, \& Weber, 1989), and comprehension strategies (Mannes, 1994) are prevalent areas of educational research. Another commonly studied class of strategies are questioning strategies (King, 1991, 1992a, 1992b). 


\section{$\underline{\text { Self-Questioning Strategies }}$}

Many study skills courses emphasize the use of questioning strategies. Students in such classes learned to successfully understand and remember their lecture notes with organization and generation of questions based upon the information presented (Laidlaw, Skok, \& McLaughlin, 1993; Spires, 1993). Kiewra (1991) described instructional aids that facilitate information acquisition during lecture presentation (e.g., cueing strategies or skeletal outline). In addition, Kiewra, DuBois, Christian, McShane, Meyerhoffer, and Roskelley (1991) found higher recall when notes were taken in matrix form. Students used similar questioning skills to generate questions from textbook headings to guide their reading. Pressley, Tanenbaum, McDaniel, and Wood (1990) also reported learner success when attempting to answer pre-questions with text readings.

Customarily, the use of questioning has been a common means of assistance in formal and academic learning. King (1991) studied questioning as more than merely gaining assistance. She addressed questioning as a means of acquiring and manipulating knowledge. Self-questioning (King, 1992a; Wong, 1985) involves active processing of information presented in lectures or some text form. Students generate and answer their own questions with the assumption that this process will focus and guide their thinking during knowledge acquisition. However, students cannot always be expected to generate quality questions to elicit explanation when instructed to interact with one another in cooperative groups. 
King (1992a) investigated the use of question scripts (or prompts) in questioning from lecture to help guide students through the content material. Question stems were developed by King (1992b) to assist learners in their effort to interact with the material and with each other. Once learners had learned how to use the script and practiced using the script, they could learn lecture material more effectively.

In general, students who receive clear instructions on question construction achieve successful results. Pressley, Johnson, Symons, McGoldrick, \& Kurita (1989) included question-generation in their review of effective strategies for improving learner's memory and comprehension of text. Questions were viewed as a means of increasing comprehension and memory and student awareness of whether they comprehended text. The authors stressed the importance of appropriate training to optimize the results of asking questions.

The current study is a type of questioning study with a focus on the specific questioning strategy called elaborative interrogation. The major difference between this research and King's research is the absence of cooperative groups. The elaborative interrogation strategy in this research is a strategy for use by individual students where King's studies were conducted on cooperative groups.

Elaborative Interrogation

The elaborative interrogation strategy differs from typical questioning strategies in that it relies heavily on the integration of prior knowledge. Learners construct inferences and elaborations in reaction to "why" questions. "It is strange that so much work has been done on questioning in the last 30 years and yet so little research has 
been done on the effect associated with generating explanatory answers to questions" (Pressley, Wood, Woloshyn, Martin, King, \& Menke, 1992, p.105).

The "mindful" construction of explanatory answers to why questions requires "inferential transformation of questioned material"(Pressley, Wood, Woloshyn, Martin, King, \& Menke, 1992, p. 91). Although people are typically able to decipher relations stated in text, they oftentimes do so superficially. These authors believe that a more thorough understanding occurs when learners construct elaborative answers to meaningful questions. Receiving explanations from other persons, however, does not have the same effect. In addition, the elaborative-interrogation procedure seems helpful when adult students are learning facts that are otherwise difficult to acquire.

In one elaborative interrogation study, Pressley, Wood, Woloshyn, Martin, King, and Menke (1992) reported generally large learning gains that occurred regardless of the quality of response to the student generated "why" questions. The latter effect may be due to the network of information that was activated in relation to each to-be-learned fact. The authors also suggested that generation of good explanations may not cause achievement, rather high achievement may be a prerequisite for having the ability to produce good explanations. Another significant finding of the study indicated that the effects of elaborative interrogation tend to be greater for adults in the application of learning facts (typically from text) or work that is novel or interesting.

An additional study of elaborative interrogation investigated learning of seventh graders presented with statements that were either consistent or inconsistent with their prior knowledge (Woloshyn, Paivio, \& Pressley, 1994). The control group 
read the sentences for understanding while learners in the experimental group answered "why" questions relying on their prior knowledge. Findings indicated that the elaborative interrogation group performed significantly better than the control group, and all participants did better on tests of recall when facts were consistent with prior knowledge. This result was likely due to the activation of meaningful prior knowledge. "Learners who generate their own questions very likely activate prior knowledge or experience relevant to their own learning needs," whereas, textbook content or questions provided by other persons may not consider the student's prior knowledge or level of interest (Pressley, Wood, Woloshyn, Martin, King, \& Menke, 1992, p. 104).

In another study, Willoughby, Wood, and Khan (1994) investigated university students and access of a highly developed knowledge base versus a less developed knowledge base within each of the following learning strategies: elaborative interrogation, imagery, keywords, and repetition. The to-be-learned content for these students was both familiar and unfamiliar. Participants were given "why" questions and told to answer them. With a low knowledge base, imagery was most effective. With a rich knowledge base, however, elaborative interrogation was most effective. These results seem to support the use of the elaborative interrogation strategy with medical students since medical students tend to have a well-developed content domain knowledge base.

Pressley, Symons, McDaniel, Snyder, and Turnure (1988) designed four experiments to investigate elaborative interrogation and another elaborative procedure 
in an incidental learning situation. The control procedures were known to improve memory of arbitrary relationships. The participants for all four studies came from a pool of undergraduates in an introductory psychology course.

The question for Experiment 1 addressed the facilitation of learning sentences containing mutually interfering content: Would elaborative interrogation work as well as imaginal encoding? Materials consisted of 48 stimulus cards with "man sentences" that referred to a specific man performing a specific action. Experiment 2 was identical except stimulus cards were replaced with image provoking slide projections. Experiments 3 and 4 contained materials representing real-world associations. The associations were not known by participants before the study, although they may have been able to interpret the associations on the basis of prior knowledge.

Overall, a clear pattern of results occurred across all four experiments. Both the elaborative interrogation and imagery procedures were more effective at facilitating memory than were reading the facts. There were no reliable performance differences between the imagery condition and the elaborative interrogation condition. The elaborative techniques were effective with both arbitrary facts and real-world relations.

The research reviewing elaborative interrogation supports the assumption that an elaborative strategy can promote better memory of expository text than reading only. Elaborative interrogation, again, is a technique for enhancing readers' comprehension by stimulating their own prior knowledge of what they are reading. Students' generation of "why" questions about material they are reading (or studying) 
prompts them to activate relevant prior knowledge. Without the questions, students may not put that knowledge to use.

The strategy research reviewed here relates to the current study in that the students of interest are adult learners with both highly developed knowledge bases and existing strategies. The content these participants learn is not incidental, it is factual, rather difficult, and expository. Also, their experience with CAI is new. It appears logical to introduce the elaborative interrogation strategy.

Strategies within Constructivism

The use of learning strategies in cognitive instruction is quite common. With the open-ended nature of constructivism, learning strategies can play a necessary role for guiding students through learning experiences. Cole (1993) examined students' comments, answers, and questions in the context of constructivism. Rather than controlling the information processing activities of the learners, this type of generative learning places the locus of control on the learners, encouraging them to become independent by learning how to learn. "As active learners, people tend to generate perceptions and meanings that are consistent with their prior learning which seems to require not only constant creation, but also reception of information and availability and activation of relevant schemata"(p. 4). Consistent with the theories of Jean Piaget (Ginsburg \& Opper, 1988) and the conceptual change literature presented by Pressley and McCormick (1995); conceptual understandings students bring to a situation play a large role in determining their understanding of the situation. If new information is inconsistent with the views already held by a learner, there is the possibility for 
cognitive conflict, which motivates efforts by the learner to comprehend the new input. Student-generated questions and comments can "scaffold" instructional design and implementation by facilitating a teacher's decomposing his or her expert knowledge (thus reaching a level that meets the needs of novices), helping the teacher assess students' prior knowledge, and providing a basis for selecting and sequencing instruction (Cole, 1993).

In summary, computer assisted instruction (mainly Hypermedia) has great potential for facilitating cognitive processing. With appropriate instruction in strategies such as questioning, coupled with sound instructional design, instructors may facilitate active participation by students when the presentation of material is greatly text. The combination of these factors has not been widely researched. The current study combines learning strategies, instructional design, and CAI into an investigation of medical student on-line curriculum.

\section{Conclusion}

Theoretically, the roots of CAI are found in behaviorism and Skinner's teaching machine. More recently, cognitive psychology has had a major influence on how computers are used in education. Currently, constructivism is the foundation for a large number of educational computer applications. Improvements in technology are helping to eliminate the boundaries within which multimedia programmers have been forced to work (Jonassen, 1988). As the focus of instructional design for computerbased learning moves from its behavioral foundations to current applications in 
constructivism, instructional designers are faced with complex decisions about how to design effective learning materials.

Wilson (1993) considers a problem of conventional instructional design as being behavioral in orientation. The research methods are behaviorally based and viewed as inconsistent with the times. He purports that instruction should not be designed to teach knowledge, rather that knowledge should be constructed by learners. Constructivism, according to Wilson, is an underlying philosophy or way of seeing the world in a way that opposes objectivism. Mental representations are just as real as the "world out there." (p. 1135). The nature of knowledge is individually and internally constructed, not located "out there." The essence of human interaction or "negotiated" meanings is of a cooperative nature rather than authoritative or manipulative. (p. 1135). Finally, the nature of science is a meaning-making activity.

As instructional design moves from the use of behavioral principles to using principles of constructivism, Hypermedia, as a form of CAI, combats the drawbacks of programmed instruction, allows for dual coding with illustrations and animations, and is commensurate with constructivism. Overall, CAI design can be improved by giving attention to effectiveness for students, appropriate incorporation into classroom activities, and improved research results.

In summary, computer assisted instruction (mainly Hypermedia) has great potential for facilitating cognitive processing. It is adaptable to individual learning styles, it allows teachers to become facilitators not deliverers, it provides a valuable window for research for designers, and it allows for individualized knowledge 
construction (Reed, Ayersman, \& Liu, 1995). With appropriate use of cognitive techniques like dual coding and knowledge construction, students can avoid finding themselves acting as passive collectors of information. The current study, therefore, investigates the benefit of an expository text learning strategy while used in a Hypermedia environment.

\section{Statement of the Problem}

Medical faculty are faced with integrating technology into the curriculum. The benefits of multimedia materials for medical students may be increased by providing learning strategies in the context of the new curriculum materials. The first research question addressed in the current study considers whether such strategy instruction benefits medical students and asked: Are there differences between groups receiving learning strategy instruction versus receiving no strategy instruction in web-based learning? Findings from previous work with elaborative interrogation indicate it is an appropriate strategy for use with expository text (Pressley, Wood, Woloshyn, Martin, King, \& Menke, 1992). These findings support the notion that college-age learners are able to use the strategy that works best when domain-specific knowledge is available. It was hypothesized that if the students used the provided CAI materials, the students in the elaborative interrogation treatment group would perform better on examinations of content.

Medical faculty are required to include on-line materials in their curriculum, the second question addressed in the current study asked: Are on-line materials better than printed materials for learning lecture content? Research on information processing, 
Hypermedia, and dual coding indicate the potential for greater retention and comprehension when using effectively designed CAI (Mayer \& Sims, 1994; Myers \& Burton, 1994; Paivio, 1971). It was hypothesized that although the benefits of CAI could facilitate learning, learners who are not familiar with learning with computers will not perform as well as learners who are more experienced at using computers in an instructional setting.

The current study was conducted with volunteers from an existing class of 87 students. The third question asked: Are volunteers different than students in the same class who declined participation? Due to the small proportion of volunteers to nonvolunteers, it was hypothesized that there is some unique quality common among the students who volunteered to participate that might limit generalizability of the research findings.

The research on computer assisted instruction, instructional design, and learning strategies is extensive. The current study extends this literature in three main ways: (a) by investigating a text processing strategy in a CAI environment, (b) by focusing on high stakes content while some of the previous research has investigated incidental learning (Pressley, Symons, McDaniel, Snyder, \& Turnure, 1988) and lower stakes learning (Willoughby, Wood, \& Kahn, 1994; Woloshyn, Paivio, \& Pressley, 1994), and (c) by selecting more advanced medical students as participants. By the selective nature of medical schools, it is assumed that medical students possess reasonable learning strategies. In addition, the second investigation compares the effects of implementing on-line materials in a medical school curriculum. 


\section{Chapter Three}

\section{Method}

The method section describes the participants, research design, and procedures used in this study. Additional information about the content of the study, and details about the intervention are provided.

$\underline{\text { Participants }}$

Twenty second-year medical students at a mid-Atlantic university volunteered to participate in the study. Participants' average age was 22 years and average incoming grade point average was 3.47 (science) and 3.55 (overall) on a 4.0 scale. All students were enrolled in a required course entitled Microbiology/Immunology. The students' previous medical school course experiences included (a) Anatomy, (b) Biochemistry, (c) Patient-centered care, and (d) Genetics. As undergraduate students, the participants primarily majored in Biological Sciences $(\underline{n}=14)$. The computer experience of the participants ranged from very little experience to skill in programming languages. The responses to the pre-survey inquiry about prior computer experience were coded as follows: $0=$ little or no computer experience, $1=$ email, word processing, web browsing, and $2=$ advanced use, programming. Eighty percent $(\underline{n}=16)$ of the students fell in the center range of experience.

Of the 87 students enrolled in the course, 30 volunteered to participate initially but only 20 completed the study. Participant attrition occurred as students failed to return their research materials prior to the study completion date. The volunteers referred to in the remainder of this paper are the 20 students who completed the study. 
The average Medical College Admission Test (MCAT) score for the entire class was 9.3 for Verbal Reasoning, 8.7 for Physical Sciences, and 9.4 for Biological Sciences. The average MCAT score for the study sample was 8.85 for Verbal Reasoning, 8.65 for Physical Sciences, and 10 for Biological Sciences. The investigation was approved by the Institutional Review Board for protection of human subjects at West Virginia University and American Psychological Association ethical guidelines were observed (See Appendix D).

$\underline{\text { Design }}$

The research design involved two treatment groups and three testing occasions. The levels of the treatment condition, Learning Strategies, were elaborative interrogation and control while the levels of the treatment condition, testing occasion, were pretest, immediate posttest, and delayed posttest. Accordingly, this is a $2 \times 3$ mixed-model design with one between-subjects independent variable, Learning Strategies, and one within-subjects independent variable, Testing Occasion. Dependent variables in the study were test score (recorded as the raw number correct on multiple choice items) and a qualitative measure, satisfaction with the method. This design is illustrated in Figure 2.

In addition to the $2 \times 3$ mixed model design, a cohort study was implemented between the prior year's class (who did not use on-line materials) compared to the Block I exam scores from this year's class (who did use on-line materials). The Block I examination is the typical in-class test of factual recognition. The to-be-learned content 
Figure 2. Illustration of research design treatment and testing conditions.

- $2 \times 3$ mixed-model design with one between-subjects independent variable (Learning Strategies) and one within-subjects independent variable (Testing Occasion).

- Number of Participants $=20$

Independent Variables

- Learning Strategies (elaborative interrogation vs. control)

- Testing Occasion (pre, immediate post, delayed post)

Dependent Variables

- Test Score (percent)

- Satisfaction with Method (qualitative)

Test Occasion

Learning Strategy Pre-test Immediate Post-test Delayed Post-test

Elaborative Interrogation

Participants Participants

1-10

1-10

Participants

1-10

Control

Participants

11-20

Participants

11-20

Participants

11-20 
for the Immunology portion of the course did not vary significantly from last year to this year. In fact, the instructional materials were simply converted from printed text to HTML with the addition of computer animations and electronic communication. The comparison of this and last years' exams was designed to determine what differences exist in the performance of the two groups of students as insight into effects of computer-based instruction.

\section{$\underline{\text { Materials }}$}

The materials for the study included the pre- and post- surveys, Block I exam, pre- and post-test examinations, on-line lecture supplement, strategy instruction, study activity matrix, and additional course materials.

Pre- and Post- Surveys. The pre-survey questions (see Appendix E) addressed the demographics of age, GPA, educational background, computer background, and interest area within medicine and was attached to the strategy instruction page for each subject. The post-survey (see Appendix F) was a three item qualitative measure of what the students thought of the computer-based materials. The data were collected in the form of open-ended question responses. The first item addressed overall satisfaction with the use of computer-based learning materials in the course, the second item asked if they would prefer this method over the traditional method of presenting learning materials, and the last item asked if they used their assigned learning strategy again after the study period. Eleven of the twenty participants responded to the postsurvey. 
Block I Exam (delayed post-test). The computerized Block I exam consisted of 76 multiple-choice questions written by the course instructors for regular classroom grading purposes. Test items pertaining to the target lectures for strategy instruction were included. These items made up approximately nine percent of the total examination. The difficulty of this test is typically greater than subsequent course examinations due to the nature of the immunology content. The exam makes up $15 \%$ of the students' course grade and a final grade of $75 \%$ or higher is considered satisfactory. Since this examination would be the first on-line testing experience for these students, a practice session was provided to help control computer anxiety. Every student in the course participated in the practice session that consisted of 15 questions from last year's Block I exam. The 15 items did not include pre-post items from this year nor items from this year's Block exam. On the day of the actual test, students were divided into two groups and tested sequentially at a campus computer lab.

Pre- and Post- Tests. The pre-test and the post-test consisted of questions from last year's Block I exam (see Appendix G). A set of nine multiple-choice questions pertaining to the target lectures was distributed on paper. The selected items were withheld from the on-line block test review that accompanied the course materials. The pre-test and post-test items were identical.

On-line Lecture Supplement. The on-line course materials served mainly as a supplement to regular lecture content. All Immunology lectures were converted to HTML but only 2 were selected for purposes of this study due to their unusual difficulty level as determined by the course coordinator. Each lecture was broken down 
into chunks of content based on major concepts. Each major concept was listed in a frame to the left of every screen. Hyperlinks connected each concept with its corresponding unit of lecture content. To the right of every screen were the corresponding chunks of information and a navigational bar which allowed the student to move sequentially between each of the major concepts (See Figure 3 for an example screen capture of a lecture page). Several lectures had computer animations to help illustrate certain concepts. The animations were linked to the overall list of concepts. Also, old Block examinations were converted to on-line testing format and provided for self-testing purposes. Both study participants and other course students could access these tests at any time and immediate feedback was provided. Email communication with the course coordinator and electronic announcements were provided throughout the semester via the course web page, as is standard in the entire on-line medical school curriculum. See Appendix $\mathrm{H}$ for a complete description of the design procedure.

Strategy Instruction. As part of regular course procedures, students were required to study two lectures on "Antigen Recognition by T Lymphocytes." This module was selected for the present investigation due to its historically challenging content. Students previously enrolled in the course have performed poorly on examinations covering these lectures and have reported difficulty understanding the content. Two types of strategy instruction were provided and illustrate one independent variable of the current study. The volunteers were randomly assigned to one of two groups ( $\underline{n}=10$ per group). One group was given instructions on using the elaborative interrogation strategy while the other group was given a set of control 
Figure 3. Example on-line content screen.

\begin{tabular}{|c|c|}
\hline $\begin{array}{l}\text { The Protein Prodects of } \\
\text { MHC Class I and Class } \\
\text { I genes }\end{array}$ & $\begin{array}{l}\text { Lecture } 7 \text { - Antigen Recognition By T Lymphocytes - Pant II } \\
\text { THE MAJOR HISTOCOMPATIBIITY COMPLEX OF GENES }\end{array}$ \\
\hline - MHC polymorphism & $\square \underline{\text { Home }} \quad \square$ Next \\
\hline $\begin{array}{l}\text { recognition } \\
\text { Other Characteristics of } \\
\text { MHC Polvmorphism }\end{array}$ & $\begin{array}{c}\text { The Major Histocompatibility Complex of Genes: Organization } \\
\text { and Polymorphism }\end{array}$ \\
\hline $\begin{array}{l}\text { - Non-self MHC molecules } \\
\text { MHC polvmorphis } \\
\text { extends the range of } \\
\text { - Muntigens } \\
\text { - Srocesses } \\
\text { The T-Cell Receptor } \\
\text { Complex } \\
\text { - The T-cell receptor } \\
\text { - The T-cell receptor }\end{array}$ & $\begin{array}{l}\text { - Key Terms: Polygenic Polymorphic MHC Restriction } \\
\text { The Major Histocompatibility Complex (MHC), called the HLA Complex in humans, } \\
\text { is uniquely equipped to handle the highly diverse array of pathogens which confront us } \\
\text { in our environment. The first means which promotes an effective immune response } \\
\text { against these pathogens is that the MHC is polygenic, in the sense that there are } \\
\text { several different class I and class II HLA genes which encode proteins for effective } \\
\text { peptide presentation to T cells. Secondly, the HLA Complex is highly polymorphic, } \\
\text { meaning that there are numerous different allelic forms for each class I and class II } \\
\text { gene. This polymorphic character of an individual's HLA genes also places rigid } \\
\text { restrictions on the mature T-cell repertoire from effector T cells can be selected in } \\
\text { mounting an immune response; thus, a T-cell can respond against a peptide antigen } \\
\text { only if it is presented by one of the "self" MHC molecules present during T cell } \\
\text { development. This important phenomenon is called "self" MHC Restriction. }\end{array}$ \\
\hline
\end{tabular}

- T-cell receptor diversity

- The co receptor molecules CD4 and CD8

- Summary

\section{Animations}

Syllabus

Schedule
- The proteins involved in antigen processing and presentation are encoded by genes in the major histocompatibility complex.

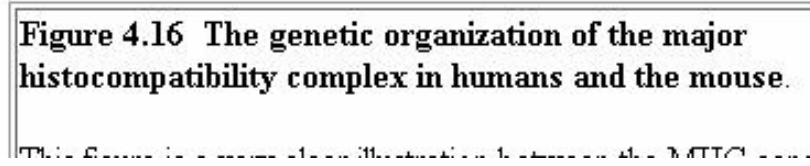


group instructions (see Figures 4 and 5 respectively). The two sets of instructions were the sole manipulation in the study. The instructions were identical except for the additional information on the experimental group instructions pertaining to the elaborative interrogation procedure. Both groups were reminded that this material is historically difficult and that study strategies can be helpful. All instructions were presented on a single sheet of paper.

Originally, the study design included a second learning strategy, an advance organizer. Due to the lack of volunteers, that condition had to be omitted. The advance organizer, a concept map of the lecture content, had been constructed prior to solicitation of volunteers. It was distributed to the participants after the present study was complete as a bonus study tool (see Appendix I).

Study Activity Matrix. A study activity matrix, used as additional qualitative self-report data, asked participants to report actual strategy use during their normal study time. The information was collected in the form of a study matrix and recorded length of time spent studying, the location at which the study session took place, and a description of the study activities for each study session (see Figure 6). It is possible that the participating students felt it was too time consuming or not worthwhile to complete.

Additional Course Materials. In addition to the on-line materials, the course also required two textbooks and additional materials for problem-based learning activities and laboratory exercises. These activities and exercises are small group assignments independent of the materials used in the current study, therefore, it is assumed these 
Figure 4. Experimental Group Strategy Instructions.

As part of this portion of the MBIM 301 course, you will be asked to follow a brief set of instructions for approaching your lecture materials. The instructions you are given will help you learn this difficult section. Please follow them carefully and do not share your instructions with others until after you complete the post-test for this section. Your cooperation is greatly appreciated.

This is a particularly difficult chapter. We want you to learn as much as possible. While you are reading this chapter, we would like you to frequently stop and ask yourself "why." Follow this procedure: 1 . Read the fact, 2. Ask why the fact would be true, 3. Generate an answer.

For example, "Why is FK506 an effective transplant rejection drug?"

This strategy will help you with this difficult content. Please record your "why" questions on this sheet of paper.

Please record your study activities as indicated on the provided matrix. . Simply narrate your study behaviors (i.e., reading, questioning, reviewing, discussing, etc). When you have finished reviewing the on-line material for lectures 6 and 7, please complete the post-test.

Return both tests and your study matrix in the provided envelope via campus mail at Health Sciences. (Lee Ann Hill, Academic Technologies, PO Box 9011)

Thank you! 
Figure 5. Control Group Strategy Instructions.

As part of this portion of the MBIM 301 course, you will be asked to follow a brief set of instructions for approaching your lecture materials. The instructions you are given will help you learn this difficult section. Please follow them carefully and do not share your instructions with others until after you complete the post-test for this section. Your cooperation is greatly appreciated.

This is a particularly difficult chapter. We want you to learn as much as possible. Please read the content carefully. This strategy will help you with this difficult content.

Please record your study activities as indicated on the provided matrix. Simply narrate your study behaviors (i.e., reading, reviewing, discussing, etc). When you have finished reviewing the on-line material for lectures 6 and 7 , please complete the post test.

Return both tests and your study matrix in the provided envelope via campus mail at Health Sciences. (Lee Ann Hill, Academic Technologies, PO Box 9011)

Thank you! 
Figure 6. Study Activity Matrix.

\begin{tabular}{|l|l|l|l|l|}
\hline Session \# & Start time & End time & Location & Study Activities Description \\
\hline example & $4: 00$ & $5: 30$ & home & $\begin{array}{l}\text { read lecture 6 notes on computer, } \\
\text { read assigned text, discussed with } \\
\text { study partner, read lecture 7, etc. }\end{array}$ \\
\hline 1 & & & & \\
\hline 2 & & & & \\
\hline 3 & & & & \\
\hline 4 & & & & \\
\hline 5 & & & & \\
\hline
\end{tabular}


activities would not have an affect on the results reported in this paper. The students were also required to complete at least 1 of 8 MICAL (Microbiology Computer Assisted Learning) courseware programs outside of the previously mentioned on-line course materials.

Procedure

The procedure for the current investigation was two part. Appendix $C$ represents a timeline for the study procedures. For the first part, as part of the course requirements, students were given access to an electronic course supplement via the World Wide Web (http://www.hsc.wvu.edu/resource/mbim). Prior to the beginning of classes, permission to conduct the study was obtained from the course coordinator, the department chair, and the dean of the medical school, and the institutional review board. Recruitment of participants took place during regularly scheduled class time. During the first week of class, a faculty member announced to the students that the study would be taking place and that it could be to their benefit to participate. Volunteerism was required since confidential scores were to be collected. The class president and academic council members were informed of the study and helped to serve as liaisons for student concerns about participation. Consent forms were then distributed and later collected by the class president who submitted them to the investigator.

The consent forms were coded. The participants were then randomly assigned to either the treatment group or the control group. Prior to the presentation of the target lectures, all participants received a research packet in their private mailboxes. The 
research packet consisted of a pre-test, a set of strategy instructions, a study matrix, a post-test, and a return envelope. Half the volunteers received the instructions for how to use elaborative interrogation as they studied, and half the volunteers received control group instructions. Participants were asked not to share the strategies with other classmates until after the study was complete. Since there was no way to monitor sharing behavior, it was assumed that students complied.

To ensure that students actually used the strategies, the elaborative interrogation group was asked to record the questions they posed during their study time on a piece of paper. See Appendix K for an example of a participant submitted "why" question. Following the target lectures, students were given approximately one week to complete their study of the materials, take the post-test, and respond to the post-survey. All materials were returned prior to the Block I exam. The Block I exam was administered at the beginning of the fourth week of class, as part of regular course procedure. Once the study was complete, students received the answers to the pre- and post- tests and a short debriefing (see Appendix I). As remuneration for participation in the study, students were given a $\$ 5$ gift certificate for the school cafeteria.

For the second part of the study, Block I exam scores of the participating students were collected from the on-line testing databank. The Microbiology/Immunology Block I exam scores of last year's second-year medical students were obtained from the course coordinator. The demographics of both groups appeared consistent although they were not subjected to an inferential test. Names were removed to maintain 
confidentiality. Twenty scores were randomly selected using a table of random numbers. 


\section{Chapter Four}

\section{Results}

Three research questions guided the study. Each research question is presented and summarized in this chapter. Data from twenty participating students were analyzed to determine the effects of using the elaborative interrogation intervention while studying an on-line lecture supplement. Further analyses included examination data from all current class members in comparison to a cohort of students from the previous academic year. Since the volunteers for the study were approximately onethird of the class population $(\underline{n}=30)$ and the study completion rate of the volunteers was $67 \%(\underline{n}=20)$, additional analyses were included to examine differences between volunteers $(\underline{n}=20)$ and non-volunteers on the regular class examination. Finally, student responses to the post-survey open-ended questionnaire were analyzed and presented as a preface to the discussion.

\section{$\underline{\text { Preliminary Analyses }}$}

Student entrance examination (MCAT) scores were compared to determine if there were pre-existing differences between the control group and the experimental group. An independent t-test was conducted; there were no statistically significant differences between the treatment and the control groups, $\underline{\mathrm{t}}(18)=-1.395, \underline{\mathrm{p}}>.05$. Means and standard deviations are presented in Table 1.

Similarly, a t-test analysis was computed to determine if there were any differences between the two groups on the immunology pre-test. Again, no differences were observed, $\underline{\mathrm{t}}(18)=-0.519, \mathrm{p}>.05$. Means and standard deviations are presented in 
Table 2. Because no differences were found between experimental and control groups on MCAT and the immunology pre-test, differences are not likely attributable to possible pre-existing differences between groups.

Table 1

Means and Standard Deviations for MCAT Scores by Group

\begin{tabular}{ll}
\hline & MCAT Scores \\
\hline Elaborative & $\underline{\mathrm{M}}=26$ \\
Interrogation & $\underline{\mathrm{S}}=3.97$ \\
& $\underline{\mathrm{n}}=10$ \\
Control & $\underline{\mathrm{M}}=29$ \\
& $\underline{\mathrm{SD}}=5.52$ \\
& $\underline{\mathrm{n}}=10$ \\
\hline
\end{tabular}

Table 2

Means and Standard Deviations for Pre-Test Scores by Group

\begin{tabular}{ll}
\hline & Pre-Test Scores [raw score (percentage)] \\
\hline $\begin{array}{l}\text { Elaborative } \\
\text { Interrogation }\end{array}$ & $\underline{\mathrm{M}}=2.50(28 \%)$ \\
& $\underline{\underline{\mathrm{n}}}=1.27$ \\
Control & $\underline{\mathrm{M}}=2.80(31 \%)$ \\
& $\underline{\mathrm{SD}}=1.32$ \\
& $\underline{\mathrm{n}}=10$ \\
\hline
\end{tabular}

\section{Research Question One}

Are there differences between groups receiving learning strategy instruction versus receiving no strategy instruction in web-based learning? 
The first research question asked if there were differences in test performance between students who received instructions for using elaborative interrogation in their study routine and students who did not receive elaborative interrogation instruction. Since a significant difference was not found between groups on pre-test scores, an independent t-test compared these two groups on post-test scores. Results indicated that there were no significant differences, $\underline{\mathrm{t}}(18)=-0.803, \underline{\mathrm{p}}>.05$. Means and standard deviations are reported in Table 3.

Table 3

Means and Standard Deviations for Post-Test Scores by Group

Post-Test Scores (raw score and percentage)

\begin{tabular}{ll}
\hline Elaborative & $\underline{\mathrm{M}}=6.70(74 \%)$ \\
Interrogation & $\underline{\mathrm{SD}}=3.12$ \\
& $\underline{\mathrm{n}}=10$ \\
Control & $\underline{\mathrm{M}}=7.30(81 \%)$ \\
& $\underline{\mathrm{SD}}=2.46$ \\
& $\underline{\mathrm{n}}=10$ \\
\hline
\end{tabular}

Within-group comparisons of pre- to post- gains were determined by paired $t$ tests. Significant differences were found for both the elaborative interrogation group, $\underline{\mathrm{t}}(9)=-5.775, \underline{\mathrm{p}}<.01$ and the control group $\underline{\mathrm{t}}(9)=-6.548, \underline{\mathrm{p}}<.01$. Means and standard deviations are reported in Table 4. This indicates that all students, regardless of their treatment condition, learned the material and performed better on the post-test of content knowledge than on the identical pre-test. 
Table 4

Means and Standard Deviations for Pre-Post Gains Scores by Group

\begin{tabular}{lll}
\hline & Pre-test & Post-test \\
\hline $\begin{array}{lll}\text { Elaborative } \\
\text { Interrogation }\end{array}$ & $\underline{\mathrm{M}}=2.50$ & $\underline{\mathrm{M}}=6.70$ \\
& $\underline{\mathrm{SD}}=1.27$ & $\underline{\mathrm{SD}}=1.77$ \\
Control & $\underline{\mathrm{n}}=10$ & $\underline{\mathrm{n}}=10$ \\
& $\underline{\mathrm{SD}}=1.32$ & $\underline{\mathrm{M}}=7.30$ \\
& $\underline{\mathrm{n}}=10$ & $\underline{\mathrm{n}}=10$ \\
\hline
\end{tabular}

A 2x3 Analysis of Variance tested for differences across all three testing situations. Only the items pertaining to the target lectures were included in the analysis of the delayed post-test. The results indicated no interaction effect, $\underline{F}(2,54)=1.514, \underline{p}>.05$. However, there was a significant main effect for the independent variable, testing occasion, $\underline{F}(2,54)=87.854, \underline{p}<.01$. In addition, no main effect was found for the independent variable, group, $\underline{\mathrm{F}}(2,54)=.009, \mathrm{p}>.05$. Means and standard deviations are located in Table 5.

\section{Research Question Two}

\section{Are on-line materials better than printed materials for learning lecture content?}

It was expected that there would be no significant differences between exam scores of last year's and this year's classes. It was hypothesized that if there were differences, this year's scores might be slightly lower due to the inclusion of on-line course materials for the first time. The 20 participants were compared to a random sample of 20 students from the prior academic year. The random sample was drawn 
Table 5

Means and Standard Deviations for Group x Testing Occasion ANOVA

\begin{tabular}{|c|c|c|c|c|}
\hline & \multicolumn{3}{|c|}{ Testing Occasion } & \multirow[b]{2}{*}{ Main Effect } \\
\hline & Pre & Post & Delayed-Post & \\
\hline Elaborative & $\underline{M}=2.50$ & $\underline{M}=6.70$ & $\mathrm{M}=8.30$ & $\mathrm{M}=5.83$ \\
\hline \multirow[t]{2}{*}{ Interrogation } & $\overline{\mathrm{SD}}=1.27$ & $\overline{\mathrm{SD}}=1.77$ & $\overline{\mathrm{SD}}=0.95$ & $\overline{\mathrm{SD}}=2.82$ \\
\hline & $\underline{\mathrm{n}}=10$ & $\underline{\mathrm{n}}=10$ & $\underline{\mathrm{n}}=10$ & $\underline{\mathrm{n}}=30$ \\
\hline \multirow[t]{3}{*}{ Control } & $\underline{M}=2.80$ & $\underline{M}=7.30$ & $\mathrm{M}=7.50$ & $\underline{M}=5.87$ \\
\hline & $\overline{\mathrm{SD}}=1.32$ & $\overline{\mathrm{SD}}=1.57$ & $\overline{\mathrm{SD}}=0.97$ & $\overline{\mathrm{SD}}=2.54$ \\
\hline & $\underline{\underline{\mathrm{n}}}=10$ & $\underline{\underline{\mathrm{n}}}=10$ & $\underline{\underline{\mathrm{n}}}=10$ & $\underline{\underline{\mathrm{n}}}=30$ \\
\hline \multirow[t]{3}{*}{ Main Effect } & $\underline{M}=2.65$ & $\underline{M}=7.00$ & $\underline{M}=7.90$ & \\
\hline & $\overline{\mathrm{SD}}=1.27$ & $\overline{\mathrm{SD}}=1.65$ & $\overline{\mathrm{SD}}=1.02$ & \\
\hline & $\underline{\mathrm{n}}=20$ & $\underline{\mathrm{n}}=20$ & $\underline{\mathrm{n}}=20$ & \\
\hline
\end{tabular}


using the Excel spreadsheet sampling feature. An independent $t$-test found no significant differences, $\underline{\mathrm{t}}(38)=-0.899, \mathrm{p}>.05$. These means and standard deviations are reported in Table 6 .

Finally, the entire class population of this year was compared to the entire class population of last year. An independent t-test found a significant difference, $\underline{\mathrm{t}}(177)=3.506, \mathrm{p}<.01$. Means and standard deviations for the entire class are also located in Table 6. Therefore, when comparing just the study sample with a random sample from the previous year, the difference in exam scores was not great enough to be significant. However, when the entire classes were included in the analysis, the students who used traditional materials (last year) performed better on the same test of content than the students who used the on-line lecture supplement (this year).

Table 6

Means and Standard Deviations for Exam Scores by Year

\begin{tabular}{|c|c|c|}
\hline & $\begin{array}{l}\text { Block Exam Scores } \\
\text { (whole class) }\end{array}$ & $\begin{array}{l}\text { Block Exam Score } \\
\text { (sample of 20) }\end{array}$ \\
\hline $\begin{array}{l}\text { Fall } 1998 \\
\text { (with on-line materials) }\end{array}$ & $\begin{array}{l}\underline{\mathrm{M}}=79.19 \\
\underline{\mathrm{SD}}=7.59 \\
\underline{\mathrm{n}}=87\end{array}$ & $\begin{array}{l}\frac{\mathrm{M}}{\mathrm{SD}}=82.50 \\
\underline{\mathrm{n}}=20\end{array}$ \\
\hline $\begin{array}{l}\text { Fall } 1997 \\
\text { (without on-line materials) }\end{array}$ & $\begin{array}{l}\underline{\mathrm{M}}=84.79 \\
\underline{\mathrm{SD}}=7.04 \\
\underline{\mathrm{n}}=92\end{array}$ & $\begin{array}{l}\underline{\mathrm{M}}=84.90 \\
\underline{\mathrm{SD}}=7.40 \\
\underline{\mathrm{n}}=20\end{array}$ \\
\hline
\end{tabular}

\section{Research Question Three}

\section{Are volunteers different than students who declined participation?}

The third research question addressed if there were differences between the students who volunteered for the study and the students who did not participate. It 
was hypothesized that given the small proportion of volunteers, those who did volunteer might somehow be different from those who did not volunteer. An independent t-test compared exam scores (delayed post-test) between the group of volunteers $(\underline{n}=20)$ and the remainder of the class $(\underline{n}=67)$. Results indicated that volunteers performed significantly better than non-volunteers, $\underline{\mathrm{t}}(85)=2.272, \underline{\mathrm{p}}<.05$. The same test performed between the 20 volunteers a random sample of 20 from the nonvolunteer group also indicated a significant difference, $\underline{\mathrm{t}}(38)=2.345, \underline{\mathrm{p}}<.05$. Means and standard deviations for both analyses are located in Table 7. Therefore, volunteers scored higher than the non-volunteers on the regular class examination.

\section{Table 7}

Means and Standard Deviations for Exam Scores by Volunteer

\begin{tabular}{ll}
\hline & Exam Score \\
\hline Volunteer Participant & $\underline{\mathrm{M}}=82.50$ \\
& $\underline{\mathrm{SD}}=7.90$ \\
& $\underline{\mathrm{n}}=20$ \\
Not a Participant & $\underline{\mathrm{M}}=78.21$ \\
& $\underline{\mathrm{SD}}=7.27$ \\
Random Sample & $\underline{\mathrm{M}}=67$ \\
Of Non-Participants & $\underline{\mathrm{SD}}=9.43$ \\
& $\underline{\mathrm{n}}=20$ \\
\hline
\end{tabular}

Qualitative Analysis

Student Generated Questions. A final qualitative analysis was conducted by the course coordinator, a subject matter expert, to determine the validity of the "why" questions posed by students in the experimental group. As a check to make sure 
students were using the intervention, they were asked to record their "why" questions on paper (See Appendix J). It was later speculated that if the questions posed by students were erroneous, their subsequent test performance would suffer. Therefore, the subject matter expert provided a manipulation check by examining the questions and answers (when provided). He determined that the questions "seemed to focus in on the relevant and important questions" and the answers were "quite good and very reasonable" (See Appendix K for full documentation). Therefore, the elaborative questions generated appeared to be accurate and commensurate with what the instructor would have considered to be important points to note.

The "why" questions were further analyzed to determine how completely the students questioned the appropriate content material. The nine items pertaining to the target lectures were isolated from the block I exam. The student submitted "why" questions were then examined individually by the subject matter expert to determine which of the block exam items they resembled. For example, the following student generated question: "Why can T cells recognize intracellular pathogens?" addresses the content of the following exam question: "Which of the following is responsible for the generation of peptide antigens from endogenous proteins for presentation to CD8+ T cells?". A summary of scores for each exam item is located in Table 8.

A total of 26 "why" questions matched one or more of the nine exam questions. Fourteen "why" questions were not related to any exam questions. Only one of the nine items was not addressed by any "why" questions. Of the remaining eight exam questions, all but one was answered correctly by the student who posed a matching 
"why" question. In other words, nearly every time a student posed a "why" question that matched an exam question, that student answered the exam question correctly.

Table 8

Analysis of "Why" Questions and Exam Questions

\begin{tabular}{ccccc}
\hline \multirow{2}{*}{$\begin{array}{c}\text { Exam } \\
\text { Item\# }\end{array}$} & $\begin{array}{c}\text { Number of "Why" } \\
\text { Questions Posed }\end{array}$ & $\begin{array}{c}\text { Number of corresponding } \\
\text { answered correctly }\end{array}$ & \multicolumn{2}{c}{$\begin{array}{c}\text { Number of Correct Answers } \\
(\underline{\mathrm{n}}=10)\end{array}$} \\
\hline 1 & 2 & 2 & 9 & Experimental \\
2 & 5 & 5 & 9 & Control \\
3 & 3 & 3 & 9 & 9 \\
4 & 5 & 4 & 7 & 10 \\
5 & 2 & 2 & 10 & 4 \\
6 & 2 & 2 & 10 & 10 \\
7 & 2 & 2 & 7 & 9 \\
8 & 5 & 5 & 10 & 5 \\
9 & 0 & 0 & 10 & 10 \\
other & 14 & $\mathrm{n} / \mathrm{a}$ & $\mathrm{n} / \mathrm{a}$ & $\mathrm{n} / \mathrm{a}$ \\
\hline
\end{tabular}

Post-survey Responses. In addition, analysis of the post-survey was conducted to determine the students' satisfaction with using the on-line learning materials. The questions posed were (a) Overall, are you satisfied with the use of computer-based learning materials in your course (on-line lecture material, electronic communication, course related animations, and computerized testing)?; (b) If you had the choice of using computer-based materials vs. traditional learning materials, which would you prefer?; (c) If you participated in the research study, did you use your assigned strategy again?; and (d) Please provide any suggestions you have for improving the current computer-based materials. The results of this survey are presented in Appendix L and discussed in Chapter Five. 
The post-survey was administered via email to the students one week following the course examination. The survey provided an open-ended format for students to describe their perceptions of the on-line course materials and strategies implementation. Of the participants who responded to the post survey (11 out of 20), the majority expressed negative reactions to the change in routine. Since few participants responded, it is possible that those who did respond had experienced dissatisfaction with the method and used this opportunity to vent their frustrations. Unfortunately, no additional data are available from those who did not respond. However, the comments were clear and very similar to the hypotheses for this study. Future studies should seek ways to elicit higher response rates by incorporating this activity in regular course procedure.

\section{Overall, are you satisfied with the use of computer-based learning materials in your course (on-line lecture material, electronic communication, computerized testing, and course related animations)?}

\section{$\underline{\text { Lecture Supplement }}$}

A few students $(\underline{n}=3)$ of the 11 respondents were excited about the innovation of computer-based learning materials and provided very positive comments. The majority, however, seemed to have some anxiety related to the change in routine, although the majority also had a reasonable amount of previous experience. The following quotation represents a common perception among the students who responded to the survey: 
"I realize the department is trying to help students by integrating the technology into our courses. However, I feel that advance notice of this decision would have improved the outcome greatly. As second-year students we were under the assumption that our courses would continue in the traditional manner for the last time and next year's class would have to deal with the changes. When you show up for the first day of class and your coordinator tells you that you're going to have to get on the web everyday for your notes your blood pressure goes up about 60 points."

Those who were surprised and anxious about this change in routine reported that it wasted their time, it hindered their progress, and it was difficult to study from the screen. Only one student, however, admitted to being "computer illiterate." There were those who chose not to use the on-line materials at all and reported doing well in the course anyway. In defense of the curricular change, one student said, "I am pleased that the microbiology department has opted to incorporate web technology into their curriculum. The on-line lecture material proved to be a valuable source of information."

Electronic Communication

Some students reported the use of electronic communication with the course coordinator $(\underline{n}=3)$. Satisfaction was most likely due to the helpful and immediate response of the faculty members and the convenience of communication at any time from any computer terminal. One student predicted more frequent electronic communication from the class of students who were required to lease laptop computers. 


\section{On-Line Testing}

All the participating students did appreciate the on-line testing component of the course. Of course, none of these students had had the experience of taking examinations on-line. The significance of this inclusion related to the fact that the national board examinations will be computerized. Students, therefore, probably perceived a practical advantage to test taking on-line.

\section{$\underline{\text { Animations }}$}

Animations did not play a major role in the reported study techniques of these students. Some simply said the animations were nice, others said they were useless. Perhaps with a more specific role in the course curriculum they would have held more importance to the students.

In summary, the students were not overly excited about a change in their method of learning, that is, the integration of on-line materials. They did, however, seem to appreciate taking tests on-line since it may serve to improve their upcoming National Board experience.

\section{If you had the choice of using computer-based materials vs. traditional learning materials, which would you prefer?}

Three of the participants who completed the questionnaire did not address this question. Six out of the eight respondents reported a preference for traditional learning materials, "Most of us come from the generation that has grown up learning from books, handouts, and writing notes with pen on paper." The remaining two respondents reported no preference and would use either computer-based learning or 
traditional methods. One's comfort level may be related to prior experience since it is unclear about how the users were affected by previous word processing or internet experiences. Reasons for choosing traditional materials include: having a developed study habit already in place, having a variety of learning strategies that utilize traditional materials, the perception that computers are not suited to study for hours late at night, and experiencing inconvenience of having to go to the computer lab to study. It was also reported that when courses use computer-based material, "it ends up being an overwhelming amount of information from too many sources."

It was expected that students would report an affinity for traditional methods, and six respondents confirmed that hypothesis. This result may be a function of computer knowledge or familiarity with the learning method. It is unknown how computer experience and general ability interact with a student's choice of one method or the other.

\section{If you participated in the research study, did you use your assigned strategy again?}

This question addresses the transfer of a newly acquired strategy, and it was anticipated that learners would transfer the strategy. Elaborative interrogation is a proven effective strategy with learners from elementary school to college; it is not difficult to learn, and therefore should transfer. Consistent with responses to the first question, respondents indicated that elaborative interrogation was very time consuming and not deemed a priority among all the responsibilities of a medical student. Six respondents answered this question, only two reported using the strategy again. The reasons reported for not using the strategy were: it was time consuming, it 
was unfamiliar, and it was difficult to change existing study habits - especially if they have worked well in the past. In addition, a student responded, “Unfortunately, medical school requires that you process a large amount of information efficiently. If I repeated the study schedule again, I would either fall behind, or lose my mind." Since some students reported no subsequent use of the strategy $(\underline{n}=4)$, the strategy was not adequately learned and did not transfer. In addition, it is unlikely that learners in the study will actively use the strategy in the future. It appears that the strategy was not a good choice for medical students regardless of the initial hypotheses.

\section{Please provide any suggestions you have for improving the current computer- based materials.}

The students did not provide suggestions for improvement. Some, however, reiterated their frustrations with the class and the intervention. They can be summarized in this response, "I really don't think that computer-based learning materials will be put to good use until we are taught how to efficiently use them. For us it may be too late. This type of curriculum needs to be taught early and used consistently throughout school."

Three students responded in a general paragraph, not addressing the above questions. Some of the perceptions reported in these paragraphs were somewhat unexpected. Students equated good teachers with the use of "old fashioned" teaching techniques, adding that "normal people hate computers," and "learning from computers will never be my main method of learning." 


\section{Chapter 5}

\section{Discussion and Conclusions}

The purpose of this research was to examine the effects of including learning strategy instruction with on-line course materials in a medical school setting. A difficult unit of course material which had been converted to on-line presentation was targeted for the intervention study. Volunteer participants were given either instruction on how to use elaborative interrogation in their study routine or control group instruction that included recording study behaviors. The study addressed three main questions.

\section{Research Question One}

Are there differences between groups receiving learning strategy instruction versus receiving no strategy instruction in web-based learning?

The results of this study indicate that although all students performed significantly better on a post-test of the content matter than on an identical pre-test, no differences between treatment groups existed (see Figure 4 for the intervention and Appendix $\mathrm{G}$ for the measurement instrument). Therefore, use of the elaborative interrogation strategy for studying course materials did not appear to produce a significant effect for this group of students. The small sample size could have contributed to the lack of significant differences. It is highly likely that the variety of anxieties held by the students at the time of the study, including anxiety related to using the web for graded course material for the first time (as indicated in the qualitative data analysis), made the situation less than ideal for introducing a new learning strategy. Although the target lectures were historically difficult and thought to 
be an incentive for students to try a new strategy, the first week of class accompanied by the unanticipated (and apparently unappreciated) news of having computerized material without prior notice seemed to affect the results. Perhaps future studies could employ participants who are more prepared to use on-line materials. The more prepared participants may be more willing to explore new learning strategies. Future studies with similar learners might be able to combat student anxiety by providing an introduction to computer-based instruction, the benefits of computer-based instruction, and some hands-on experience.

It is equally important to consider the caliber of students who participated in this study. Medical students are generally students who were at the top of their undergraduate class. It is probable that these students came to medical school with a set of very effective learning strategies -- perhaps perceived as more effective than the elaborative interrogation strategy. These pre-existing strategies are practiced, known to be effective, and are not a risk. The methodology of this study consciously targeted a unit of material that was historically difficult for students to master, it may have been difficult for them to adopt an unfamiliar strategy at a point where competition to make good grades overrides participation in a research study. Winne (1995) and others discuss the point of competing learning goals when a strategy is introduced simultaneously with new content (Pressley, 1995; Boekarets, 1995).

An additional consideration of the strategy recommendations concerns the recording of study behavior (see Appendix $\mathrm{M}$ for actual data). Reports in the postsurvey indicated that at least one student in the control group thought that the 
recording of study behavior was a strategy in itself. Since every participant of the study was asked to record study activities, it is possible that this activity served as a strategy for both groups. Perhaps consciousness of study behaviors prompted the students to expend more time and effort and perhaps additional strategies in exam preparation which resulted in improved performance.

The course faculty assisted in the promotion of the research and the organization of the methodological logistics. These faculty, however, were not in favor of taking time out of the students' class period. It was necessary, therefore, to make the intervention as unobtrusive as possible, thus a one-page set of instructions distributed via campus mailbox served as the intervention. The lack of personal contact made it very difficult to teach the strategy properly and to motivate students to participate. Since the materials were returned via campus mail, attrition may have occurred due to lost papers or similar neglect. Future research in this area should concentrate on a more in-depth and personal intervention, rather than a one-page description of the strategy.

To summarize possible implications for future research on learning strategies in on-line courses, students need to be aware and comfortable with the curricular changes involved in implementing technology as well as with the use of technology itself. The researcher needs to be present during the intervention, in the distribution and collection of materials, as well as in the teaching of the strategy. Finally, selection of strategies that complement existing strategies possessed by medical students may be more effective in the context of computer-based instruction. 


\section{$\underline{\text { Research Question Two }}$}

\section{Are on-line materials better than printed materials for learning lecture content?}

The second research question used a cohort group to address the overall success of using an on-line lecture supplement. The lack of improved test scores and the reported dissatisfaction of many students indicates the need for a different approach to presenting on-line learning materials. The institution at which this study took place was in its first semester of implementation of an on-line curriculum. The target course was among the first to be presented so future improvements are expected. It is not uncommon for the presentation of on-line information to be difficult at first (Quigley, 1994; Rogers \& Laws, 1997). Based on post-survey responses, students in this study had a clear affinity for traditional teaching and learning methods. Perhaps the technical difficulty of accessing the internet was a factor. Students without home access had to conform to computer center hours of operation and the distractions that occur there. Students with computers at home not only complained about the time and expense it takes to gain access from home but also about the trouble with networks being down or having incompatible hardware and software. With improvements in computer equipment and connections, these factors will be reduced. Fluency with on-line materials will also improve as younger students gain more experience using computers before reaching medical school. If this study were to be replicated as soon as next year, the results would probably differ due to the fact that the students will be leasing laptop computers. In addition, they will have had the computers for a full year prior to the beginning of the course. 
It was obvious that the inclusion of an on-line testing situation was preferable to these students over the mere posting of course materials. The on-line tests served a dual-role for all students in the course. First, they met a course requirement and second they provided experience that will help students as they take the on-line board examination. Practitioners should be aware of the anxiety these students experienced as they were informed they would have computerized tests in the course. For these students who are highly motivated by grades, being tested in an unfamiliar environment created some anxiety. Due to this reaction, the design team implemented a practice session that successfully alleviated a great deal of tension.

\section{Research Question Three}

\section{Are volunteers different than students who declined participation?}

The final research question sought to determine if differences exist between those who volunteered to participate in this research study and those who declined. Since the entire class was approached and only one third of the members agreed to participate, it was hypothesized that there was something unique about the volunteers that prompted them to take part. Speculations included prior levels of achievement. If the volunteers were overachievers, perhaps they sought to stay ahead of the others. If the volunteers were underachievers, perhaps they realized that status and thought the strategy could help them improve their learning. Although demographic and survey data were collected from the study participants, that information is not available for the remainder of the class. The only available measurement for both volunteers and non-volunteers was block exam score. The analysis indicated that the volunteers scored significantly 
higher on the block exam than did the non-volunteers. Perhaps the volunteers were overachievers as discussed before.

\section{General Study Limitations}

There are a number of factors that could be considered limitations in this study. The greatest of which is the small sample size. As discussed previously, the lack of volunteers could be due to the timing of the study, the nature of medical students (high achievement levels and competition for grades), the lack of personal contact by the researcher, the nature of the study (strategy research with a population who may already use strategies they perceive as effective), or other stressors (introduction of technology in the curriculum). Some of these issues may be conquered as students become more comfortable with technology. While these are valid considerations, it is necessary to examine the intervention itself. The one page, brief description of how to use a strategy without verbal explanation may not have been sufficient. While the effectiveness of the intervention may be questionable, given the setting it was the only option for the current study. Other issues, such as the possession of existing strategies, will need to be researched to ascertain what strategies they do use and how they can be improved to fit the framework of computer-based instruction.

The pre-post measurement instrument may have been a limitation for two reasons. First, the number of items used to assess very complex knowledge may have been inadequate. Although the study took place in conjunction with two one-hour lectures on Immunology and the items selected were taken from an actual examination containing the same content, it may have been prudent to add further measures of 
comprehension. In addition, there may have been carry over effects from using the same test to measure pre-post knowledge over a short period of time (about 10 days). The students in either study group may have used the pre-test to guide their review of the content. Although the answers were not provided until after the study was complete, students may have located the answers during the treatment phase and thus performed better on the post-test independently of the treatment. Therefore, the time period between pre- and post-tests may be a consideration.

Since the control group was led to believe they were participating in a study of learning strategies, asking them to record their study behaviors could have served as a strategy in itself. It is possible that the control group experienced the same study effect as the experimental group, as indicated by the post-survey response of one student. Future studies may consider using a less obtrusive activity for the control group or simply use a more blind presentation of the research goals.

Another reason for the lack of significant findings may have been due to participants in the treatment group sharing notes with participants in the control group. Since the students' study time was not supervised, this sharing activity is very difficult to monitor and, therefore, was not controlled in this study. Future studies could implement controlled study sessions. This, however, would limit generalizability of the findings.

Finally, the use of MCAT scores may have been an inappropriate measure of potential pre-existing differences. It is understood that board examinations are highly stressful for potential medical students and may not be a true representation of one's 
ability. Grade point average, although not available for all participants in this study, may be a better dependent measure for future studies.

\section{$\underline{\text { Future Research }}$}

This study could easily be replicated in the next academic year. If it were to be repeated, the course structure would dictate the methodology change such that the intervention is a part of regular course activity. As part of course procedures, the intervention may either seem like either less of an intrusion or less trivial. The intervention should take place face-to-face over a longer period of time so students have the opportunity to ask for clarification or further examples of the strategy in use. Students should be made more aware of the challenges facing them academically and technologically and guided through recommendations for improving study habits. At a better time of the semester, a time when students are settled and comfortable in the course (or any other course of study), more participants may volunteer.

To address the strategy issues, further research should examine strategies that could be more appropriate for medical students and on-line learning. Subsequent studies would also include a survey of existing learning strategies. Finally, improved response to items such as the post survey could be elicited by incorporating the intervention into regular course procedure and/or providing bonus points for participation.

It is difficult to know, by the results of this study, how computer experience and general ability interact with a student's choice of method. Future research should address these factors. In addition, future research needs to examine variables that 
contribute to the successful integration of computers in instruction. Variables of interest include prior computer experience, prior knowledge, domain specific knowledge, and flexibility in strategy use.

\section{Conclusions for Future Practice}

While many faculty members in Health Sciences, as well as other disciplines, are facing the inclusion of technology in the curriculum, designers of such instruction should consider not only the quality of the instructional materials but also the potential effect on students who use them. Once the need has been determined and the development plan is in place, it is important to formatively evaluate such innovations to find out how students react. If students are uncomfortable with certain technologies, instructors should present the materials gradually, with frequent communication and feedback. If a need for better strategies is sought, the instructor or designer should assess what the students are doing currently and research strategies that would serve as a supplement or improvement to existing strategies. New strategies may even help students as they make the transition from traditional to technological teaching and learning methods.

Students in a medical school curriculum tend to be very motivated, very skilled, and rather anxious. They are concerned about class standing and the ability to pass the national board examinations, creating a stressful situation (Helmers, Danoff, Steinert, Young, \& Leyton, 1997). Learning a new strategy is deemed as one more thing to be anxious about. Previous research in elaborative interrogation had looked at younger and or less skilled learners (Pressley, Johnson, Symons, McGoldrick, \& Kurita, 1989; 
Willoughby, Motz, \& Wood, 1997) in a low-stakes environment. In a situation such as that, the strategy may have helped students more. Further research should be done to isolate learning strategies that fit the needs of the medical student, and future practice should help the students use such strategies in a low-stress, scaffolding situation.

The balance between computer-based instruction and traditional methods of teaching and learning is precarious for practitioners since learners with low computer knowledge tend to have high anxiety (Reed \& Overbaugh, 1993). When they are ultimately faced with some computer-based experience and they are overwhelmed and dissatisfied with learning the content the anxiety seems to persist. It seems as though a combination of both traditional book learning and lecture contact with the added benefit of CAI supplements could be most appropriate way for computer-based materials to enhance traditional methods of teaching.

Finally, it is obvious that students in the present study had an affinity for traditional methods of teaching. Until technology actually becomes more traditional than innovative, instructors should use technology as a supplement to familiar instructional practices. 


\section{References}

Anderson, J. R. (1990). Cognitive Psychology and its Implications. New York: W.H. Freemand and Company.

Billings, D. M. (1986). Computer Assisted Instruction for Health Professionals: A Guide to Designing and Using CAI Courseware. Appleton-Century-Crofts, East Norwalk, CT.

Boekarets, M. (1995). Self-regulated learning: Bridging the gap between metacognitive and metamotivation theories. Educational Psychologist, 30, 195-200.

Bransford, J. D., \& Johnson, M. K. (1972). Contextual prerequisites for understanding: Some investigations of comprehension and recall. Journal of Verbal Learning and Verbal Behavior, 11, 717-726.

Buck, M. (1995). The impact of electronic visualization: Concerns and delimitations. (ERIC Document Reproduction Service No. ED 380 091)

ChanLin, L. (1994). A theoretical analysis of visual learning implications for computer graphics design. (ERIC Document Reproduction Service No. ED 370 526)

Cobb, P. (1988). The tension between theories of learning and instruction in mathematics education. Educational Psychologist, 23, 87-103.

Cognition and Technology Group at Vanderbilt (1991). Some thoughts about constructivism and instructional design. Educational Technology, 31(9), 16-18.

Cole, P. (1993). Learner generated questions and comments: Tools for improving instruction. In: Proceedings of selected research and development presentations at the convention of the Association for Educational Communications and 
Technology. (15th. New Orleans, Louisiana. January 13-17). (ERIC Document Reproduction Service No. ED 362 160)

Duffy, T. M., \& Jonassen, D. H. (1992). Constructivism and the Technology of Instruction. Hillsdale: Lawrence Erlbaum Associates.

Garmston, R., \& Wellman, B. (1994). Insights from constructivist learning theory (How to make presentations). Educational Leadership, 51(7), 84-86.

Ginsburg, H. P., \& Opper, S. (1988). Piaget's Theory of Intellectual Development. New Jersey: Prentice-Hall.

Glenberg, A. M. (1986). Enhancing Calibration. Program Report 86-14. (ERIC Document Reproduction Service No. ED 273 935)

Gredler, M. E. (1997). Learning and Instruction. New Jersey: Prentice-Hall.

Helmers, K. F., Danoff, D., Steinert, Y., Young, S. N., \& Leyton, M. (1997). Stress and depressed mood in medical students, law students, and graduate students at McGill University. Academic Medicine, 72, 708-714.

Jonassen, D. H. (Ed.) (1988). Introduction to Instructional designs for Microcomputer Courseware. Hillsdale: Lawrence Erlbaum Associates.

Jonassen, D. H. (1991). Objectivism vs. constructivism: Do we need a new philosophical paradigm shift? Educational Technology: Research \& Development, 39, $5-14$.

Jonassen, D. H. (1994). Technology as cognitive tools: Learners as designers. Unpublished paper.

Kiewra, K. A. (1991). Aids to lecture learning. Educational Psychologist, 26, 37- 
53.

Kiewra, K. A., DuBois, N. F., Christian, D., McShane, A., Meyerhoffer, M., \& Roskelley, D. (1991). Note-taking functions and techniques. Journal of Educational Psychology, 83, 240-245.

King, A. (1991). Effects of training in strategic questioning on children's problem-solving performance. Journal of Educational Psychology, 83, 307-317.

King, A. (1992a). Comparison of self-questioning, summarizing, and notetakingreview as strategies for learning from lectures. American Educational Research Journal, $\underline{29}, 303-323$.

King, A. (1992b). Facilitating elaborative learning through guided studentgenerated questioning. Educational Psychologist, 27, 111-126.

Laidlaw, E. N., Skok, J., \& McLaughlin, M. (1993). The effects of notetaking and self-questioning on quiz performance. Science Education, 77, 75-82.

Levin, J. R. (1983). Pictorial strategies for school learning: Practical illustrations. In M. Pressley \& J. R. Levin (Eds.), Cognitive Strategy Research: Educational Applications (pp. 213-237). NY: Springer-Verlag.

Mannes, S. (1994). Strategic Processing of Text. Journal of Educational Psychology, 86, 577-588.

Mayer, R. E., \& Anderson, R. B. (1992). The instructive animation: Helping students build connections between words and pictures in multimedia learning. Journal of Educational Psychology, 84, 444-452.

Mayer, R. E., \& Sims, V. K. (1994). For whom is a picture worth a thousand 
words? Extensions of a dual-coding theory of multimedia learning. Journal of Educational Psychology, 86, 389-401.

Myers, R. J., \& Burton, J. K. (1994). The foundations of hypermedia: Concepts and history. Computers in the Schools, 10(1-2), 9-20.

Nelson, W. A. (1993). Efforts to improve computer-based instruction: The role of knowledge representation and knowledge construction in hypermedia systems. Computers in the Schools, 10, 1-32.

Paivio, A. (1971). Imagery and Verbal Processes. New York: Holt, Rinehart, \& Winston, Inc.

Perkins, D. N. (1991). Technology meets constructivism: Do they make a marriage? Educational Technology, 31(5), 18-23.

Poohkay, B. \& Szabo, M. (1995, February). Effects of animation \& visuals on learning high school mathematics. Proceedings of the Annual Meeting of the Association for Educational Communications and Technology, Anaheim, CA.

Pressley, M. (1995). More about the development of self-regulation: Complex, long-term, and thoroughly social. Educational Psychologist, 30, 207-212.

Pressley, M., Johnson, C. J., Symons S., McGoldrick, J. A., \& Kurita, J. A. (1989). Strategies that improve children's memory and comprehension of text. The Elementary School Journal, 90, 3-32.

Pressley, M., \& McCormick, C. B. (1995). Advanced Educational Psychology. New York: Harper Collins College Publishers.

Pressley, M., Symons, S., McDaniel, M. A., Snyder, B. L., \& Turnure, J. E. (1988). 
Elaborative interrogation facilitates acquisition of confusing facts. Journal of Educational Psychology, 80, 268-278.

Pressley, M., Tanenbaum, R., McDaniel, M. A., \& Wood, E. (1990). What happens when university students try to answer prequestions that accompany textbook material? Contemporary Educational Psychology, 15, 27-35.

Pressley, M., Wood, E., Woloshyn, V. E., Martin, B., King, A., \& Menke, D. (1992). Encouraging mindful use of prior knowledge: Attempting to construct explanatory answers facilitates learning. Educational Psychologist, 27, 91-109.

Quigley, D. (1994). The evolution of an online syllabus. Computers and Composition, 11(2),165-172.

Reed, W. M., Ayersman, D. J., \& Liu, M. (1995). The effect of hypermedia instruction on stages of concern of students with varying authoring language and prior hypermedia experience. Journal of Research on Computing in Education, 27(2-3), 297317.

Reed, W. M., \& Overbaugh, R. C. (1993). The effects of prior experience and instructional format on teacher education students' computer anxiety and performance. Computers in the Schools, 9 , 75-89.

Rieber, L. P. (1990). Animation in computer-based instruction. Educational Technology Research \& Development, 38(1), 77-86.

Rieber, L. P. (1991). Animation, incidental learning, and continuing motivation. Journal of Educational Psychology, 83, 318-328.

Rogers, C., \& Laws, P. (1997). Successes and lessons learned in an on-line course 
on socioemotional development. (ERIC Document Reproduction Service No. ED 415 830)

Salomon, G., Perkins, D. N., \& Globerson, T. (1991). Partners in cognition: Extending human intelligence with intelligent technologies. Educational Researcher, $\underline{20,} 2-9$.

Scheidler, K. (1993). Students cross discipline boundaries with hypermedia. The Computing Teacher, 1(2), 16-20.

Schwier, R. A. \& Misanchuk, E. R. (1995, February). The art and science of color in multimedia screen design. Paper presented at the Annual Conference of the Association for Educational Communications and Technology, Anaheim, CA.

Simonson, M. R., \& Thompson, A. (1997). Educational Computing Foundations. Merrill Prentice-Hall: New Jersey.

Skinner, B. F. (1989). Programmed instruction revisited: Excerpts from another paper on teaching machines. In Recent Issues in the Analysis of Behavior. Merrill Publishing Company: Columbus, $\mathrm{OH}$.

Smeaton, A. (1991). Using hypertext for computer-based learning. Computers in Education, 17(3), 173-179.

Spires, H. A. (1992). Learning from a lecture: Effects of comprehension monitoring. Reading Research and Instruction, 32, 19-30.

Vargas, E. A., \& Vargas, J. S. (1991). Programmed instruction: What it is and how to do it. Journal of Behavioral Education, 1, 235-251.

Wager, W., \& Lebow, D. G. (1995, February). Teaching alternative strategies 
with alternative teaching strategies: Reflection on constructivist course design. Paper presented at the annual meeting of the Association for Educational Communication and Technology, Anaheim, CA.

Weinstein, C. E., Ridley, D. S., Dahl, T., \& Weber, S. (1989). Helping students develop strategies for effective learning. Educational Leadership, 46, 17-19.

West, R.P., \& Hamerlynck, L.A. (Eds.) (1992). Designs for Excellence in Education: The Legacy of B. F. Skinner. Sopris West, Inc: Longmont, CO.

Willoughby, T., Motz, M., \& Wood, E. (1997). The impact of interest and strategy use on memory performance for child, adolescent, and adult learners.

Alberta Journal of Educational Research, 43(2-3),127-138.

Willoughby, T., Wood, E., \& Khan, M. (1994). Isolating variables that impact on or detract from the effectiveness of elaboration strategies. Journal of Educational Psychology, 86, 279-289.

Wilson, B. G. (1993). Constructivism and instructional design: Some personal reflections. In: Proceedings of selected research and development presentations at the convention of the Association for Educational Communications and Technology. (15th. New Orleans, Louisiana, January 13-17). (ERIC Document Reproduction Service No. ED 362 213).

Winne, P. (1995). Inherent details in self-regulated learning. Educational Psychologist, 30, 223-228. 
Woloshyn, V., Paivio, A., \& Pressley, M. (1994). Use of elaborative interrogation to help students acquire information consistent with prior knowledge and information inconsistent with prior knowledge. Journal of Educational Psychology, 86, 79-89.

Wong, B. Y. L. (1985). Self-questioning instructional research: A review. Review of Educational Research, 55, 227-268. 
Appendix A

Suggestions for Creating Constructivist Materials 


\section{Suggestions for Creating Constructivist Materials}

\begin{tabular}{|c|c|}
\hline Community & Work collaboratively on the course design \\
\hline Generativity & $\begin{array}{l}\text { Avoid lectures - in order for students to become self directed } \\
\text { and responsible learners, instructors must turn from the } \\
\text { transmission of knowledge to the director of learning } \\
\text { activities }\end{array}$ \\
\hline Collaboration & Increase social interaction with small collaborative groups \\
\hline Personal autonomy & $\begin{array}{l}\text { Engage students in the discussion of course purposes and } \\
\text { how best to reach them }\end{array}$ \\
\hline Transformation & $\begin{array}{l}\text { Be flexible - if things are not going as planned be open to } \\
\text { change }\end{array}$ \\
\hline Self-regulation & $\begin{array}{l}\text { Be professional in the creation of a learning environment } \\
\text { and the evaluation of student work - decide ahead of time } \\
\text { what productions will demonstrate achievement of the } \\
\text { course goals, and how they will be graded }\end{array}$ \\
\hline Authenticity & $\begin{array}{l}\text { Be authentic - focus on what the learners will do when they } \\
\text { leave the institution }\end{array}$ \\
\hline
\end{tabular}




\section{Appendix B}

Introductory Frames on Morphemes 


\section{Introductory Frames on Morphemes}

1. One aspect of linguistics is the analysis of words into the smallest units that carry meaning. The study of such word parts is an area of study in $1_{---}--_{-}--$. (linguistics)

2. The smallest word parts that carry meaning are morphemes. In the word "unhappy," the part "un-" means "not." Therefore, "un-" is a $\mathrm{m}_{-}{ }_{-}{ }_{-}{ }_{-}$. (morpheme)

3. Some words are composed of only one morpheme or unit of meaning. An example is cat. In this case, the morpheme making up the word is $\ldots-{ }_{-}$. (cat)

4. Sometimes morphemes may be added to existing words, for example, the letter "s." When added to some words, "s" means "more than one." In such a situation, the "s" is a

5. Of course, some letters do not carry any meaning in words, such as the "s" in "slide." In this case, "s" is _ _ a morpheme. (not)

6. Some words are composed of two or more morphemes. An example is "biology" which includes "bio_" (life) and "_logy" (study of). Biology, therefore, is composed of . (two morphemes)

7. The word "morpheme" itself may be analyzed as follows: "Morph_" = unit or form and"_eme" = "small." The complete word is composed of . (two morphemes)

8. Prefixes and suffixes are word parts that frequently function as units of meaning. An example is "pre_" (before or prior) as in "preview." In this example, the prefix is also a (morpheme)

9. In the earlier example, "un_"in "unhappy" was identified as a morpheme. This prefix is a morpheme because it is a $u_{-}$ (unit of meaning)

10. Language includes two kinds of morphemes, one of which is "free morphemes." They are the smallest unit of meaning that can stand alone. For example, in the word "cats," the word part "cat" is a . (free morpheme)

11. Some words are composed only of free morphemes. The word "cowboy" is composed of two free morphemes. They are ${ }_{-}$and $_{-}{ }_{-} \cdot(\mathrm{cow}, \mathrm{boy})$

12. The other type of morpheme is a "bound morpheme." It is a unit of meaning that cannot stand alone. For example, the morpheme "s" in the word "cats" is a $-{ }_{-}-{ }_{-}-\ldots$ (bound morpheme)

13. The letter "s" in the word "cats" is a bound morpheme because it is a unit of meaning that can/cannot stand alone. (cannot)

14. Some words may be composed of only bound morphemes. An example is the word "biology," composed of "bio_" and "_logy." This word includes two (bound morphemes)

15. Still other words, like "cats," may be composed of both bound and free morphemes. Another example is the word "unhappy," which includes morpheme and bound morpheme. (one, one) free 
Appendix C

Timeline of Study Procedure 


\section{Timeline of Study Procedure}

April - July:

Design on line lecture supplement/tests

August 1-21:

-Course coordinator meetings for research procedures

-IRB approval obtained

August 25:

-Plug study in class

August 26:

-Collect consent forms

August 27:

-Distribute study materials

-Students take pre-test and pre-survey

August 28:

-Students attend lectures

August 28-September 4:

-Students use strategies, take post-test and return materials

September 14:

-Block I exam

September 15:

-Complete post-survey

-Debriefing

-Remuneration distributed
April

May

June

July

August

September 


\section{Appendix D}

Consent and Information Form 


\section{Consent and Information Form}

Introduction. I, have been invited to participate in this research study which has been explained to me by Lee Ann Hill. This research is being conducted to fulfill the requirements for a doctoral dissertation in Educational Psychology at West Virginia University.

Purposes of the Study. The purpose of this study is to learn more about the inclusion of learning strategies within on-line course material.

Risks and Discomforts. There are no known or expected risks from participating in this study, except for the mild frustration associated with performance of the pre-test.

Benefits. I understand that this study is not expected to be of direct benefit to me, but the knowledge gained may be of benefit to others. I will not receive extra credit in my MBIM 301 class for participation.

Contact Persons. For more information about this research, I can contact Lee Ann Hill, at 2931906, or her supervisor, Dr. Rayne Dennison, at 293-2515. For information regarding my rights as a research subject, I may contact the Executive Secretary of the Institutional Review Board at 293-7073.

Confidentiality. I understand that any information about me obtained as a result of my participation in this research will be kept as confidential as legally possible. I understand also that my research records, just like hospital records, may be subpoenaed by court order or may be inspected by federal regulatory authorities. In any publications that result from this research, neither my name nor any information from which I might be identified will be published without my consent.

Voluntary Participation. Participation in this study is voluntary. I understand that I am free to withdraw my consent to participate in this study at any time. Refusal to participate or withdrawal will involve no penalty or loss of benefits and will not affect my grades or class standing. I have been given the opportunity to ask questions about the research, and I have received answers concerning areas I did not understand.

Upon signing this form, I will receive a copy.

I willingly consent to participate in this research. As part of the study, I willingly consent to the anonymous release of my MCAT scores and my MBIM 301 Block exam scores.

Signature

Date

Signature of Investigator

Date 
Appendix E

Pre-Survey 


\section{Pre-Survey}

Age

GPA/Class standing

Educational background

Computer background (How have you used computers prior to this course?)

Interest area (within medicine) 


\section{Appendix $F$}

Post-Survey 


\section{Post-Survey}

1. Overall, are you satisfied with the use of computer-based learning materials in your course (on-line lecture material, electronic communication, course related animations, and computerized testing)?

2. If you had the choice of using computer-based materials vs. traditional learning materials, which would you prefer?

3. If you participated in the research study, did you use your assigned strategy again? 


\section{Appendix G}

Pre- and Post- Test 


\section{Pre- and Post- Test}

\section{Antigen Recognition by T Lymphocytes I}

1. A cytosolic protein that is the source of an antigenic peptide recognized by cytotoxic $\mathrm{T}$ lymphocytes is most likely degraded into peptide fragments
a. in the endosome
b. in the endoplasmic reticulum (ER).
c. by the proteasome.
d. by the chaperone protein, called calreticulin.
e. in the Golgi apparatus.

2. Which one of the following is NOT associated with the class II MHC antigen presentation pathway?
a. tapasin
b. endosome
c. HLA-DM
d. endoplasmic reticulum (ER)
e. invariant chain.

3. The T cell coreceptor molecule that interacts with class II MHC molecules is called ?
a. HLA-DM
b. $\quad$ CD8
c. Invariant chain
d. Calnexin
e. $\mathrm{CD} 4$

4. Which of the following is NOT normally involved in CTL recognition of foreign antigen?
a. $\quad$ self peptide
b. $\quad$ self MHC class I molecule
c. foreign (nonself) peptide
d. $\quad$ CD8
e. TCR $\alpha \beta$ heterodimer

5. In a T helper cell response, the coreceptor molecule interacts with 

a. the $\beta_{2}$ domain of a class II MHC molecule.
b. the $\alpha 3$ domain of a class I MHC heavy chain.
c. the $\beta 2$-microglobulin light chain of a class I MHC molecule.
d. the TAP-1 chain of the TAP transporter.
e. none of the above

6. The MHC peptide binding cleft has
a. tyrosine kinase activity.
b. $\quad \alpha$-helix regions and $\beta$-strands.
c. an $\alpha \beta$-chain heterodimer structure.
d. DNA-binding activity.
e. none of the above.

7. T helper cell recognition generally requires with the $\mathrm{MHC}$ /peptide complex.
a. TCR $\alpha \beta$ and CD8 binding
b. TCR $\gamma \delta$ and CD8 binding
c. TCR $\gamma \delta$ and CD4 binding
d. TCR $\alpha \beta$ and CD4 binding
e. $\quad$ CD3 binding

8. The structure of a class I MHC molecule contains
a. $\quad \alpha 1, \alpha 2$, and $\alpha 3$ domains; and $\beta 2$-microglobulin.
b. $\quad \alpha 1$ and $\alpha 2$ domains and $\beta 1$ and $\beta 2$ domains.
c. an $\alpha \beta$-chain heterodimer.
d. a CD4-binding site in the $\alpha 3$ domain.
e. A CD8-binding site in the $\beta 2$ domain.

9. A class II HLA gene which encodes a protein involved in the class I MHC presentation pathway is
a. TAP-2.
b. HLA-DM.
c. Ii (invariant chain).
d. $\quad \beta 2$-microglobulin.
f. none of the above. 


\section{Appendix $\mathrm{H}$}

Design of On-line Course Supplement 


\section{Design of On-line Course Supplement}

The development team was given a floppy disk containing 18 text documents representing the past years' lecture supplement for the Immunology portion of the course Microbiology/Immunology 301. Three Graduate Assistants worked under the direction of an Instructional Designer in conjunction with the subject matter experts to convert these documents into HTML format. The design team met on a bi-weekly basis over a four-month period to complete the project. Approval from the department chair and the course coordinator was obtained after outlining the screen design and again after the content had been formatted.

Once all the content was converted and all links were in place, six medical students were asked to participate in a field trial. Their comments were taken into consideration and the final product was given approval by the appropriate faculty before the materials were implemented that fall. 
Appendix I

Student Debriefing 


\section{Student Debriefing}

Thank you for your participation in the MBIM 301 research study. The following is a brief explanation of the learning strategies selected for this investigation. Attached you will find the answers for the pre/post test and your cafeteria certificate. You can use your certificate anytime this semester but you must use it all at once since no change can be given at the cash register. Good luck on the Block exams! Lee Ann

\section{Elaborative Interrogation:}

Elaborative Interrogation is a higher order questioning strategy which encourages students to connect new information to their own well-developed knowledge base. Instead of presentation and memorization of facts, students are asked to construct and answer a "why" question for each fact. Research has shown this strategy to be helpful in learning textual material.

\section{Advance Organization:}

Advance Organizers in the form of concept maps identify the key concepts inherent in the material and visually represent the relationships between concepts. By presenting the concept map prior to introduction of new material, students are given a well-organized knowledge structure with which to relate more detailed information.

Advance Organizer for Antigen Recognition by T Lymphocytes

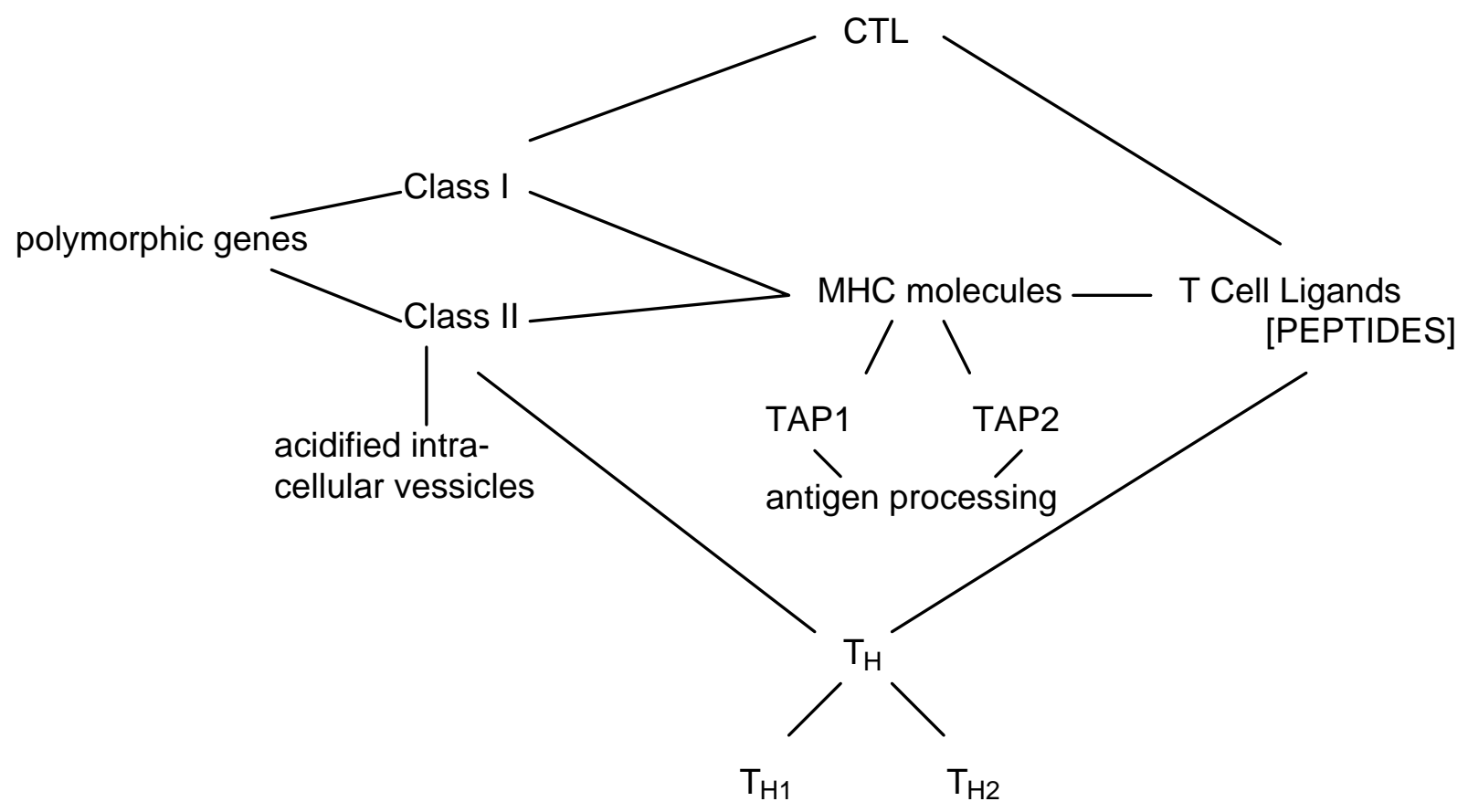




\section{Appendix J}

"Why" Questions Submitted by Students 


\section{"Why" Questions Submitted by Students}

$\underline{\text { Student A }}$

1. Why does polymorphitism of MHC genes help counter viruses who target MHCs machinery?

2. Why are most M0 | in the thymic medulla when apoptosis occurs in the thymic cortex?

\section{Student B}

1. Is Ag in endosome degraded in a specific way?

2. Does endosome fuse with lysosome or "become" lysosome?

3. Where is HLA DM made - is it bound to mite II in ER?

4. How do T cells identify self from nonself?

\section{Student C}

1. Why are there 2 separate molecules for antigen presentation?

2. Why is it logical that cells presenting class I should be directly killed by CD8 T-cells?

3. Why aren't "self" peptides presented in MHC molecules?

4. Why do CTLs only recognize specific MHC molecules?

5. Why is HLA-DM gene expression stimulated by interferon $Y$ ?

6. Why does somatic hypermutation not occur in T-cell receptor generation?

7. How exactly do seperantigens bind MHC and TCRs.

8. Why do they cause CD4s to release cytokines (which cytokines)?

9. Why is the J region the most varied region on TCRs?

\section{Student D}

1. Why can $\mathrm{T}$ cells recognize intracellular pathogens?

Infected cells have the ability to display on their cell surface peptide fragments derived from pathogen proteins. These fragments are bound to MHC molecules.

2. Why do T cells have to be able to recognize peptides produced in 2 different intracellular compartments?

Because viruses and some bacteria replicate the cytosol, while other bacteria and parasites replicate in endosomes. This is why there are 2 different ways of processing and presenting antigens.

3. Why are the peptides that stimulate $\mathrm{T}$ cells recognized only when bound to MHC molecules?

T cells only respond to short amino acid sequences. These short sequences are usually found buried within the protein. Proteins have to be broken down and the short amino acid sequences presented in presence of MHC for T cells to recognize them. 
4. Why is the MHC molecule able to bind peptides with high affinity and still be able to bind a wide variety of different peptides?

First, the binding of peptide is stabilized at its two ends. The atoms in the free amino and carboxy termini bind to invarient sites in the peptide-binding groove of all MHC molecules. These interactions provide broad peptide MHC specificity. Second, MHC molecules have certain anchor residues, which are certain amino acid residues lining pockets in the MHC molecules. The anchor residues interact with amino acid side chains on the antigenic peptide, strengthening the bond. The anchor residues are determined by allelic varients of MHC molecules. All of this applies to MHCI molecules.

5. Why is the length of peptides bound to MHC class II molecules not constrained?

Peptide fragments are allowed to hang over the edges of class II MHC. The termini do not bind to invarient regions. Binding occurs $\mathrm{b} / \mathrm{t}$ the peptide residues and anchor residues.

6. Why is class I MHC found on all nucleated cells?

Class I MHC presents cytosolic proteins i.e. viruses. Since all nucleated cells can become virally infected, they all need MHCI to tell the immune system they're infected.

7. Why are class II MHC found only on cells that participate in immune response?

Class II MHC is recognized by CD4(TH) cells. Since the main job of CD4 cells is to activate other immune effector cells, class II MHC is limited mainly to the antigen presenting cells.

\section{Student E}

1. Why do you never see class I MHC on the cell surface without protein?

Class I MHC alone is very unstable. It has to bind to protein to become stable.

2. Why is the proteasome important in class I MHC presentation?

The proteasome degrades proteins in the cytosol into smaller peptide fragments that can be recognized by class I MHC.

3. Why is the invarient chain important to class II MHC presentation?

Ii binds to the MHC molecule in the endoplasmic reticulum, preventing it from binding to peptides or partially folded proteins. Ii also targets the delivery of MHC class II molecules from the ER to an endosome.

4. Why is HLA-DM needed for MHC class II presentation?

HLA-DM is an MHC-like molecule that catalyzes the release of the clip fragment from MHCII molecules. This takes place in the endosome and alows binding of peptide to the MHC. Until peptide binding occurs. HLA-DM keeps MHC stable. 
5. Why does the typical person express 6 different MHC class I molecules and 8 different MHC classs II molecules on his/her cells?

This is due to the polygenic, polymorphic nature of the MHC. Polygenic $=$ more than one gene for each molecule. Polymorphic $=$ more than one allele for each gene .

Co-dominance also plays a part. The products of both alleles are expressed on the same cell.

6. Why is polymorphism so important?

For one, it allows great diversity in antigenic peptide recognition. For another, it makes it harder for pathogens to escape being detected, even if they mutate. They can only change so many things.

7. Why is the diversity of the antigen-binding site much greater in Ig than in the TCR?

TCR's do not undergo somatic hypermutation like Ig.

8. Why is the absence of somatic hypermutation in the TCR benefical?

It helps to ensure that somatic mutants that recognize self-proteins do not arise later in development. This is important since $\mathrm{T}$ cells are responsible for initiating and propagating immune responses.

9. Why is this not as important for B cells?

$B$ cells require $T$ cell initiation - B cells that react to self-antigen would find it hard to find a $\mathrm{T}$ cell that also reacts to the same self antigen to activate it.

10. Why is superantigen binding to TCR's not a beneficial immune reaction?

Superantignes are not processed. They bind directly to MHC II and the TCR causing the CD4 T cells to produce massive amounts of cytokines. The cytokines cause systemic toxicity and suppress the adaptive immune response.

11. Why does rearrangement of the TCR and chain genes cause inactivation of the 8 chain genes?

The 8 chain gene complex is located entirely within the alpha chain gene complex $\mathrm{b} / \mathrm{t}$ the $\mathrm{V}$ and $\mathrm{J}$ genes. When alpha gene rearrangement occurs, all of the 8 genes get spliced out. 


\section{Appendix K}

Subject Matter Expert Assessment of Questions and Answers Generated by the Students 


\section{Subject Matter Expert Assessment of Questions and Answers Generated by the Students}

I am really amazed at how well these students responded in this exercise! First of all, they seemed to focus in on the relevant and important questions important in understanding the topic of "Antigen Presentation and T Cell Recognition". They covered most of the important questions. Also, there were no "stray" questions asked which do not impact on improving their understanding of this topic. Finally, for those questions that the students attempted to answer, the answers generated were quite good and very reasonable. After reviewing these questions, and accompanying answers, I would declare this project an UNQUALIFIED SUCCESS!

James M. Sheil, Ph.D.

Associate Professor of Microbiology \& Immunology

Course Coordinator for MBIM 301 - Fall, 1998 
Appendix L

Post-Interview Data 


\section{Post-Interview Data}

\section{Overall, are you satisfied with the use of computer-based learning materials in your course (on-line lecture material, electronic communication, course related animations, and computerized testing)?}

a. I am pleased that the microbiology dept. has opted to incorporate web technology into their curriculum. The on-line lecture material proved to be a valuable source of information. However, the material lacked homogeneity. A single format needs to be developed that correlates with the lecture material. The dept. needs to decide if they will use a text when teaching the class, or rely on the on-line information as the basis for learning, with texts as reference.

I like the comprised testing, although the tests were not without their problems. The software used for testing needs to have some changes made. The grade being shown upon completion caused significant distress to several students. It was also difficult to go back and find questions that were not answered or that needed to be reviewed during the test. As for electronic communication, Dr. Sheil has been extremely receptive to e-mail, other professors I can not comment. Although our class uses e-mail much less than next year's. Over all, I must say that I am not dissatisfied. There are bugs to be worked out, but it is a good start.

b. I definitely prefer on-line testing to filling in circles. I didn't really use the computerized syllabus because I just recently purchased a computer. I thought the animations weren't that useful. There's nothing wrong with them, but they didn't really enhance my understanding much. I would have valued the chance to do more problem solving things on the computer. For next year, I think it would be helpful to find websites that offer good quizzes related to the material we're studying -- both clinical and basic science aspects.

c. Overall, I really don't find it that much different from the traditional way of learning in class. It is nice to be able to get updated info off of the web site, especially if the lecture material has been changed. Most of us use printed copies of the lectures in class and during study, just as if it had been one of our printed syllabi. We don't study directly from a computer because either we don't know how or don't feel comfortable in doing things that way. Course related animations are very helpful, but they are not used very often. Computerized testing is good in ways and bad in ways. I like the format, no bubbles to fill in. It doesn't take as long, and I've been able to adapt to it. What is bad is when the test doesn't load well, when questions need changed, when trying to evaluate your test and it looks so much different than the answer sheet, etc.

d. My only experience is with the testing--and it has been a positive experience 
e. To be honest, I haven't really used them and I do fine in the class. Actually, I think if I spent time trying to look at things on the computer it would only hinder my progress. The computerized testing actually worked well except for typos and inappropriate questions. Some thought should be given to a way to make checking the test afterwards a little easier.

f. NO! I cannot see the value of having the lecture notes on computer. For other classes we buy a hard copy of the notes from the copy center; this takes a maximum of 15 minutes for the entire semester's material. For this class we have to access the web, find the notes and print them out; this takes CONSIDERABLY longer than 15 minutes. My conclusion is that the only thing the computer does for me in this instance is to waste time. Fortunately, we have one person in our class who does this for us each week and provides us with the weeks material. This way it only costs one person that time.

You may wonder why we want a hard copy of the notes. There are two reasons that I want them. Firstly, it is useful to have the notes during the lecture: some lecturers have all of the material in the notes so one does not need to add anything, others do not have all the information in the notes so it is useful to add to the notes during the lecture. Secondly, It is difficult to study for tests from a computer screen. Most people use the notes and highlight important points and make summaries. It is a lot more tiring reading from a computer screen.

I have not used the animations.

I think the computerized testing is a good idea especially since the Board will be computerized. I find it very helpful to have a pencil and paper available during the exam. However, being somewhat computer illiterate I have not yet figured out how to access my exams afterwards and I think that learning from ones mistakes on the exam is important. I have heard people say that we should not have access to our exams because we won't have access to our Board exams after we have taken them. While this is true, part of the purpose of this class is to prepare us for the Boards and I think that learning from ones mistakes is an important part of this process.

I think that having the ability to e-mail professors with questions is extremely useful, especially since it is often difficult to find people between classes.

g. This was the first class I have ever been required to use the computer for. At first I thought it was frustrating but after a few weeks it became more like normal. Overall, I liked the on-line materials (especially the animations) and the computerized testing (since the boards will also be computerized). I did not use the electronic communication. I prefer face to face.

h. Yes 


\section{If you had the choice of using computer-based materials vs. traditional learning materials, which would you prefer?}

a. I would choose traditional. It is more comfortable for me at this point, as I have developed a system for study that incorporates outside resources a variety of learning strategies.

b. For learning materials, I prefer paper. It helps me process the information better.

c. Since I use them in the exact same way, I guess I would have to say the traditional method.

d. A bit of both--I still enjoy reading books, but the computer testing is very efficient

e. Computer-based materials are a good enhancement, but most of us come from the generation that has grown up learning from books, handouts, and writing notes with pen on paper. Learning from computers will never be my main method of learning. Too often also, when courses try to include computer material, it ends up being an overwhelming amount of information from too many sources. Additionally, our class does not have laptop computers and for me going to the computer lab is sometimes inconvenient.

f. Traditional

g. It doesn't matter, either one is fine.

h. Traditional

3. If you participated in the research study, did you use your assigned strategy again?

a. Yes

b. A little. I generate questions a little more often now as I study. That's about the only part I use. I don't keep a log.

c. No, I did not. I feel that it is time consuming because I am not very familiar with it. It is very hard to change your habits once you have established something that works for you.

d. $n / a$

e. No. I have a certain way to study and old habits are hard to change, especially ones that work well. 
f. No

g. $n / a$

h. No

\section{Please provide any suggestions you have for improving the current computer- based materials.}

a. If I think of anything else, I will let you know.

b. See question 1. Also, it would be helpful if all of the lecturers' slides were on the website.

c. I really don't think that computer-based learning materials will be put to good use until we are taught how to efficiently use them. For us it may be too late. This type of curriculum needs to be taught early and used consistently throughout school. I'm sorry that I cannot provide any useful suggestions.

d. None at the moment

e. Next year I think it will be more helpful since the first years have their own computer.

f. They ought to be useful and not simply time consuming. I cannot think of a way to make them useful. I appreciate the opportunity to express my opinions.

g. None

h. None

\section{Condensed responses to Questions 1-4}

i. My response to the survey is as follows:

While I was initially excited to enter this new curriculum, I have been very disappointed with the way the school has implemented it. A short story to illustrate my point. Last year, our class rated all of the teachers in our curriculum. The top teachers, in my opinion and in several of my classmates opinions, were Dr. X, Dr. Y, and Dr. Z. All three of them had one thing in common, THEY USED OLD FASHION TECHNIQUES TO TEACH. The first two used the chalkboard and Dr. Miles used an overhead projector. What this curriculum has turned into is teachers making fancy powerpoint presentations, putting they up in a nice format and read the info to us. The 
teaching skills have been replaced by fancy lecture slides. A teacher is supposed to teach and that is something that special person is hard to find at this medical school. In my opinion, only one department in this school understands how to PROPERLY implement this technology--the Anatomy dept. Dr's A and B should be commended on using the computers and a helpful SUPPLEMENT to the curriculum and not relying on it. They would teach in traditional ways, and then guide us through lab using the computer slides--not just saying, "it's here on the computer for you all to look at it." My overall reaction to the new system is that it is beneficial if implemented properly. If the departments can't and aren't willing to do this, then they should refrain from using the computer-based curriculum. I hope this message gets to the people it should because there are some serious problems with the way several of the departments are using this program.

j. I realize the department is trying to help students by integrating the technology into our courses. However, I feel that advance notice of this decision would have improved the outcome greatly. As second-year students we were under the assumption that our courses would continue in the traditional manner for the last time and next year's class would have to deal with the changes. When you show up for the first day of class and your coordinator tells you that you're going to have to get on the web everyday for your notes your blood pressure goes up about 60 points. My point is normal people hate computers. I hate logging on to the net, waiting for pages to download, waiting for my printer to "spool" or whatever it does. When I got this news, I had to go out and replace my broken modem, install it and sit on the help line with IBM for about 16 hours total. I then had to find a server for the net. I lost \$15 bucks on WVNET because my system "wasn't compatible with theirs" and never got a refund for the initial month that I paid. In conclusion, a nice simple letter this summer informing us of these changes would have left me a lot better prepared for this and I probably wouldn't have failed the first test.

k. Computerized testing is a great idea, unfortunately the situation open the door for cheating. Also, the testing program needs to be updated. It was inadequate for revisions after the test making some grades invalid. As far as I know everyone printed the lectures off the computer to study. Animations were helpful. Computers are not suited to study 6 hrs late at night. Also, I would love to be able to study as complete as suggested in the prescribed study schedule. Unfortunately, med school requires that you process a large amount of info efficiently. If I repeated the study schedule again, I would either fail behind, or lost my mind. Thanks, 
Appendix M

Study Matrix Data 


\section{Study Matrix Data}

Experimental Group

\begin{tabular}{|c|c|c|c|c|}
\hline Session \# & Start time & End time & Location & Study Activities Description \\
\hline A1 & 10:00pm & $10: 50 \mathrm{pm}$ & Home & Read \& highlighted text 4.1-4.2 \\
\hline A2 & 9:00pm & $10: 50 \mathrm{pm}$ & Home & Read \& highlighted text 4.2-4.46 \\
\hline A3 & 4:00pm & 4:00pm & Home & $\begin{array}{l}\text { Read \& highlighted lectures } 6 \& 7 \\
\text { printouts from computer }\end{array}$ \\
\hline B1 & 8:30am & 10:30am & Home & $\begin{array}{l}\text { Read lecture } 6 \& 7 \text { on paper while } \\
\text { looking at figures in book. No } \\
\text { computer used!! }\end{array}$ \\
\hline $\mathrm{C} 1$ & $5: 30 \mathrm{pm}$ & 9:30pm & Study room & $\begin{array}{l}\text { Read chapter } 4 \& \text { lecture notes } \\
\text { printed from computer }\end{array}$ \\
\hline D1 & $8: 00$ & 9:00 & Home & $\begin{array}{l}\text { Read assigned text for lecture } 6 \\
\text { and followed with lecture } 6 \text { notes } \\
\text { on computer }\end{array}$ \\
\hline D2 & 11:15am & 11:55am & School & Same as above \\
\hline$\overline{\mathrm{D} 3}$ & $7: 45 \mathrm{pm}$ & 9:30pm & Home & $\begin{array}{l}\text { Read text and computer notes for } \\
\text { lecture } 7\end{array}$ \\
\hline E4 & 7:00 & 8:00 & Home & Review path notes \\
\hline E5 & 8:00 & 9:00 & Home & Review micro notes \\
\hline E6 & 9:00 & 10:00 & Home & Preview micro notes \\
\hline$\overline{E 7}$ & 10:00 & 11:00 & Home & Preview path notes \\
\hline F1 & $12: 30$ & 1:40 & Home & $\begin{array}{l}\text { Print notes for lecture } 6 \& 7 \text {, read } \\
\text { notes and textbook and make } \\
\text { summary for part of lecture } 6\end{array}$ \\
\hline $\mathbf{F} 2$ & 1:55 & 2:50 & Home & $\begin{array}{l}\text { As above - finish lecture } 6 \text { and } \\
\text { start lecture } 7\end{array}$ \\
\hline F3 & 3:10 & 4:00 & Home & As above lecture 7 \\
\hline F4 & 4:50 & 5:05 & Home & As above lecture 7 \\
\hline G1 & 4:00 & 8:00 & $\begin{array}{l}\text { Study } \\
\text { lounge }\end{array}$ & $\begin{array}{l}\text { Started reading chapter } 4 \text { and } \\
\text { making an outline. Read lecture } \\
\text { notes for lecture } 6\end{array}$ \\
\hline G2 & 10:00am & $12: 00 \mathrm{pm}$ & Home & Finished reading and outlining ch 4 \\
\hline G3 & 2:00pm & $2: 30 \mathrm{pm}$ & $\begin{array}{l}\text { Computer } \\
\text { lab }\end{array}$ & $\begin{array}{l}\text { Attempted to view animations but } \\
\text { couldn't download shockwave in } \\
\text { the CBLC }\end{array}$ \\
\hline
\end{tabular}




\begin{tabular}{|c|c|c|c|c|}
\hline$\underline{\mathrm{H} 1}$ & $7: 30$ & 11:00 & $\begin{array}{l}\text { Evansdale } \\
\text { library }\end{array}$ & $\begin{array}{l}\text { Read chapter } 6 \text { then read relevant } \\
\text { lecture notes }\end{array}$ \\
\hline H2 & 8:00 & 11:00 & $\begin{array}{l}\text { Evansdale } \\
\text { library }\end{array}$ & $\begin{array}{l}\text { Read chapter } 4 \text { then read relevant } \\
\text { lecture notes }\end{array}$ \\
\hline H3 & 7:30 & $10: 00$ & $\begin{array}{l}\text { Evansdale } \\
\text { library }\end{array}$ & $\begin{array}{l}\text { Finish reading chapter } 4 \text { and } \\
\text { lecture notes }\end{array}$ \\
\hline H4 & 9:00 & 11:00 & $\begin{array}{l}\text { Evansdale } \\
\text { library }\end{array}$ & $\begin{array}{l}\text { Read chapter } 5 \text { then read relevant } \\
\text { lecture notes }\end{array}$ \\
\hline H5 & 8:00 & 11:00 & $\begin{array}{l}\text { Evansdale } \\
\text { library }\end{array}$ & $\begin{array}{l}\text { Read chapter } 8 \text { then read relevant } \\
\text { lecture notes }\end{array}$ \\
\hline I1 & $1: 00$ & 3:00 & School & Went to class, listened to lectures \\
\hline $\mathrm{I} 2$ & 8:00 & $8: 30$ & Home & Read over lecture notes \\
\hline I3 & $2: 30$ & $4: 50$ & Home & $\begin{array}{l}\text { Read assigned reading for lecture } 6 . \\
\text { Wrote and answered "why" } \\
\text { questions. Studied lecture notes }\end{array}$ \\
\hline I4 & $5: 00$ & $7: 30$ & Home & $\begin{array}{l}\text { Read assigned reading for lecgture } \\
\text { 7. Wrote and answered "why" } \\
\text { questions. Studied lecture notes }\end{array}$ \\
\hline I1 & $7: 30$ & 7:50 & Home & $\begin{array}{l}\text { Wrote and reviewed lecture } 6 \& 7 \\
\text { notes, looked at figures in book for } \\
\text { clarification }\end{array}$ \\
\hline $\mathbf{J} 2$ & $3: 30$ & 4:00 & $\begin{array}{l}\text { Computer } \\
\text { lab }\end{array}$ & $\begin{array}{l}\text { Read through website and wrote a } \\
\text { few notes on lecture } 6 \& 7 \text { material }\end{array}$ \\
\hline J3 & 4:10 & 4:30 & $\begin{array}{l}\text { Student } \\
\text { lounge }\end{array}$ & $\begin{array}{l}\text { Read/skimmed p. } 1-20 \text { chapter } 4 . \\
\text { Made chart on MHCI vs. MHCII } \\
\text { (thought book didn't add much } \\
\text { new info so didn't read entire } \\
\text { chapter) }\end{array}$ \\
\hline J4 & $4: 30$ & 4:35 & & Took post test \\
\hline
\end{tabular}

\section{Control Group}

\begin{tabular}{|l|l|l|l|l|}
\hline Session \# & Start time & End time & Location & Study Activities Description \\
\hline K1 & $5: 15$ & $6: 05$ & Home & $\begin{array}{l}\text { Read lecture 6 notes and } \\
\text { corresponding references to text }\end{array}$ \\
\hline K2 & $7: 30$ & $8: 15$ & Home & $\begin{array}{l}\text { Review lecture 7 notes and used } \\
\text { corresponding text }\end{array}$ \\
\hline$\underline{\text { L1 }}$ & $5: 30$ & $\mathbf{6 : 3 0}$ & Home & $\begin{array}{l}\text { Started reading lecture 5 notes } \\
\text { concurrently with book. Took notes } \\
\text { on my notes from explanatory info } \\
\text { in book. }\end{array}$ \\
\hline L2 & $\mathbf{1 2 : 0 0}$ & $\mathbf{2 : 0 0}$ & Home & Continued, finished lecture 5 in \\
\hline
\end{tabular}




\begin{tabular}{|c|c|c|c|c|}
\hline & & & & $\begin{array}{l}\text { above manner, read in book to end } \\
\text { of chapter } 5 \text { lecture material }\end{array}$ \\
\hline L3 & $5: 30$ & 8:00 & School & $\begin{array}{l}\text { Reading lecture } 5 \text { notes/book in } \\
\text { above manner. Notes by figure } \\
\text { (notes for each overhead put up), } \\
\text { read and highlighted important } \\
\text { material in book }\end{array}$ \\
\hline L4 & $10: 30$ & $1: 30$ & Home & $\begin{array}{l}\text { Finished lecture } 6 \text {, using above } \\
\text { manner. Occasionally reviewed old } \\
\text { mateiral to keep it straight }\end{array}$ \\
\hline L5 & 9:30 & $12: 30$ & Home & Read lecture 7/notes, same fashion \\
\hline M1 & $12: 15$ & $12: 35$ & Home & Read lecture 6 notes on paper \\
\hline M2 & $1: 00$ & $3: 00$ & Class & Attend lectures $6 \& 7$ \\
\hline M3 & 6:30 & 10:30 & Home & $\begin{array}{l}\text { Read lecture } 6 \& 7 \text { notes on paper, } \\
\text { follow along with figures in the text } \\
\text { while reading lecture notes }\end{array}$ \\
\hline M4 & $10: 30 \mathrm{pm}$ & $10: 45$ & Home & Took post-test \\
\hline N1 & $11: 00 \mathrm{pm}$ & 1:00am & Home & Read lecture notes on computer \\
\hline $\mathrm{O} 1$ & $2: 30$ & $3: 00$ & $\begin{array}{l}\text { Computer } \\
\text { lab }\end{array}$ & $\begin{array}{l}\text { Reviewed notes on computer for } \\
\text { lecture } 6 \& 7\end{array}$ \\
\hline $\mathrm{O} 2$ & 11:00 & $11: 30$ & Home & Read lecture notes for lectures $6 \& 7$ \\
\hline P1 & 9:15 & 10:00 & Home & $\begin{array}{l}\text { Read chapter } 4 \text { in text for lecture } 6 \\
\text { (page 4:1-4:19) read lecture } 6 \text { notes } \\
\text { from web page }\end{array}$ \\
\hline P2 & 6:00 & 7:00 & Home & $\begin{array}{l}\text { Read rest of chapter } 4 \text { and read } \\
\text { lecture } 7 \text { notes from web page }\end{array}$ \\
\hline $\mathrm{Q} 1$ & 7:00 & 9:00 & Med center & Read chapter 4 \\
\hline $\mathrm{Q} 2$ & 9:00 & 11:00 & Med center & Read lecture $6 \& 7$ notes (printed out) \\
\hline R1 & 7:00 & $8: 30$ & Home & Read lecture $6 \& 7$ notes \\
\hline R2 & 8:00 & 11:00 & Home & Read text \\
\hline R3 & $12: 00$ & 1:00 & $\begin{array}{l}\text { Study } \\
\text { lounge }\end{array}$ & Read lecture $6 \& 7$ notes \\
\hline S1 & 9:30 & $12: 00$ & $\begin{array}{l}\text { Student } \\
\text { lounge }\end{array}$ & Read assigned text \\
\hline S2 & 10:30 & $12: 00$ & $\begin{array}{l}\text { Student } \\
\text { lounge }\end{array}$ & $\begin{array}{l}\text { Read medical microbiology and } \\
\text { immunology section on immunology }\end{array}$ \\
\hline
\end{tabular}




\title{
LEE ANN HILL
}

\author{
1 Cedarstone Drive \\ Morgantown, WV 26505 \\ 304-598-2982 \\ lhill@wvu.edu
}

\section{Education}

West Virginia University, Morgantown, WV

Doctor of Education, May 1999

Major: Educational Psychology Minor: Instructional Design \& Technology

West Virginia University, Morgantown, WV

Master of Arts, December 1993

Major: Educational Psychology

Wheeling Jesuit College, Wheeling, WV

Bachelor of Arts, May 1991

Major: Psychology

\section{Employment Experience}

Instructional Designer (March 1998 - present)

Academic Technologies, Health Sciences Center, West Virginia Univeristy

Guided multidisciplinary teams in the instructional design and development process, mainly using technology. Projects involved direct contact with HSC faculty and support staff from intake to completion. Consulting included software recommendations and use, instructional techniques, HTML development, and online testing. Also provided workshops for training faculty on design issues, web course development, software use, and courseware development.

Graduate Assistant (October 1996 - March 1998)

WV K-12 RuralNet Project, West Virginia University

Participated in development, implementation, and evaluation of an on-line course for teaching WV K-12 Science educators how to incorporate the internet in their classes. Responsibilities include teaching summer on-site workshops, serving as an on-line mentor, and conducting qualitative program evaluation research. Also, developed mentoring guide for teacher leaders.

Graduate Teaching Assistant (September 1994 - October 1996)

Computer-based Learning Center/Academic Technologies, West Virginia University Assisted Health Sciences faculty with instructional design applications. Coordinated 
computer courseware design team including content expert and graphic artist. Provided Authorware consultation for faculty. Conducted faculty workshops (Authorware \& PowerPoint). Worked on team for Web-based instruction.

Research Assistant I (September 1993 - August 1994)

Department of Clinical Pharmacy, West Virginia University

Major responsibilities include using Authorware Professional for authoring, troubleshooting, evaluating, and distributing a variety of pharmacy courseware.

Programs include a variety of topics, interactions, graphics, and animations.

Responsibilities previously included downloading, transcribing, coding, analyzing, and organizing data from on-line computer database searches.

Graduate Teaching Assistant (August 1992 - August 1993)

Department of Educational Psychology and Foundations, West Virginia University Instructed freshman study strategies course for two semesters and provided input for future course changes. Assisted faculty members with summer course in educational research and spring course in child development.

Graduate Research Assistant (August 1991 - August 1992)

Department of Educational Psychology and Foundations, West Virginia University Assisted professors in educational research using computer spreadsheet, computer generated graphs, and data analysis software; concept map coding; and library research skills.

\section{Software Development Experience (HTML and Authorware)}

Web-based course supplements - HTML pages for Microbiology, Evidence Based Medicine, Pharmacy and other health science departments

"Histology for Dental Hygienists" - Graphic intensive courseware designed for dental hygiene students and adapted for a wider range of health science students.

"Evaluation of Pharmacokinetic Literature" - Animation based courseware for teaching kinetics concepts.

"Evaluation of Clinical Drug Studies" - Hypertext courseware for helping students learn to critically evaluate drug efficacy literature.

"An Introduction to Statistics for Medical Research Studies" - Hypertext tutorial created with Hypercard to simplify basic statistical concepts. Template for a series of Problem Based Learning Cases

\section{Teaching Experience}

Workshops:

Using Computers for Instruction

Teaching Scholars Program, Health Sciences, West Virginia University (Spring 1999) 
Faculty Development Series:

1. Authoring and Presentation Software, 2. Instructional Design, 3. Online Testing

Academic Technologies, Health Sciences, West Virginia Univeristy (Summer-Fall 1998)

Introduction to Authorware and Authorware Intermediate

Academic Computing, West Virginia University (Fall 1997 and Spring 1998)

Instructional Materials: Design, Development and Implementation"

Faculty Development Workshop, West Virginia University (Spring 1997)

Authorware and Powerpoint

Computer-based Learning Center, Health Sciences, West Virginia University (19941995)

West Virginia University Courses:

Ed Psych 351 - Instructional Design_(Fall 1996)

Team taught comprehensive ID course for technology education graduate students

Ed Psych 191 - Learning Strategies for Academic Success (Fall 1992 \& Spring 1993)

Conducted undergraduate course concerning effective study techniques, problem solving, and time management

Ed Psych 320 - Introduction to Educational Research (Summer 1993 \& Spring 1994) Assisted with group work and grading of graduate course in research methodology

Ed Psych 391 - A Time to Grow (Spring 1994)

Assisted with organization, correspondence, and grading of televised graduate course in child development

\section{Publications}

Hill, L.A. (1995). Book Review: Instructional Designs for Microcomputer Courseware. David H. Jonassen (Ed). Computers in Human Behavior, (11), 665-666.

Haught, P.A., Hill, L.A., Walls, R.T., Nardi, A.H. (1998). Improved learning and study strategies inventory (LASSI) and academic performance: The impact of feedback on freshmen. Journal of the First Year Experience, (10), 25-40.

Haught, P.A., Hill, L.A., Nardi, A.H., Walls, R.T. (1999). Perceived ability and level of education as predictors of traditional and practical adult problem solving. Experimental Aging Research in press. 


\section{Research Experience and Conference Presentations*}

“Young Children's Problem Solving and Self-Regulation” with Rayne S. Dennison

*American Educational Research Association (AERA), Montreal, (April 1999)

"Concept Identification, Practical Problem Solving, and the Problem Solving Inventory" with Patricia A. Haught and Anne H. Nardi

*AERA, San Diego, CA (April 1998)

"Mentoring an Online Course: Problems, Pitfalls and Solutions" with Marcia Marcolini *AACE WebNet, Toronto, Canada (November 1998)

"Integrating Technology and Psychology" MWC Faculty Collaboration with Bruce Macewen

*Faculty Academy, Mary Washington College, Fredericksburg, VA (July 1997)

"Developing Appropriate Instructional Materials: A Case-Based Approach" with Marcia Marcolini, Kim Kavanagh, and Rayne S. Dennison

*Eastern Educational Research Association (EERA), Hilton Head, SC (February 1997)

“Theory of Mind in Metacognitive Problem Solving Ability in Young Children" with Rayne S. Dennison

*EERA, Hilton Head, SC (February 1997)

"Graphics and Animation in Computer-based Instruction: Rationale and Formative Evaluation"

*International Society for Exploring Teaching Alternatives (ISETA), Columbus, $\mathrm{OH}$ (October 1996)

"Evaluation of Jr. Metacognitive Awareness Inventory" with Rayne S. Dennison, Cheryl Murphy, and Bruce Howard

*AERA, New York, NY (April 1996)

"Formative Evaluation of an Authorware Program for Dental Histology"

*Association for Education Communication and Technology (AECT), Indianapolis, IN (February 1996)

"The Impact of Feedback on the Learning and Study Strategies Inventory on Student Academic Performance" with Patricia A. Haught, Richard T. Walls, and Anne H. Nardi *EERA, Boston, MA (February 1996) 
"The Long Term Effects of Completing a Comprehensive Study Strategies Course" with Patricia A. Haught

*EERA, Boston, MA (February 1996)

"Learning Strategies for Academic Success" with Patricia A. Haught

*ISETA, Bloomsburg, PA (October 1995)

"Social Problem Solving in Preschoolers" - Masters Thesis (Dec 1993)

*EERA, Hilton Head, SC (March 1995)

"The Effects of Experience on State Size Perception" (April 1991) with Teresa Keys

*Kent State University conference for undergraduate psychology majors

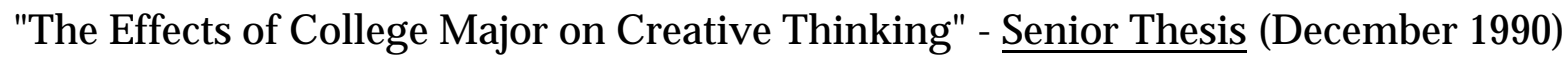

Computer Software Experience

Macintosh and Windows platforms:

Authorware PowerPoint

Director

Hypercard

HoTMeTal

Word and Wordperfect

Excel

Systat Nudist

\section{Professional Affiliations}

Current Membership:

American Education Research Assocation (AERA)

Association for Educational Communications and Technology (AECT)

\section{Service and Search Committees}

Search committee for Clinical Associate, Academic Technologies (Fall 1998)

Search committee for Research Instructor, WV K-12 RuralNet Project (Spring 1997)

Search committee for Professor of Statistics, Educational Psychology (Spring 1996)

Reviewed paper proposals for Studying and Self-Directed Learning SIG of AERA 1997 